\title{
Estudo dos efeitos da prednisona sobre o sistema mucociliar de ratos
}

Tese apresentada à Faculdade de Medicina da Universidade de São Paulo para obtenção de Título de Doutor em Ciências

Programa de: Cirurgia Torácica e Cardiovascular Orientador: Prof. Dr. Paulo Manuel Pêgo Fernandes

SÃo PAULO

2010 



\section{Dedicatória}

À minha mãe, dona Libera, pelo exemplo e por me impulsionar em TODAS as conquistas. Admiro muito sua coragem e sua força. Agradeço por ser sua filha.

Ao meu marido, meu querido Henrique, companheiro em todas as horas, admirado na vida e na profissão.

Ao meu filho, Bruno, que mesmo aqui de dentro já é responsável por tantas alegrias e transformações na minha vida. Presença tão recente, mas que já é a razão maior que me faz seguir, construir, conquistar, ser feliz.

Amo vocês! 


\section{Agradecimentos}

Aos meus irmãos Carlos, Eduardo e Anderson pelo carinho, apoio, pela união pouco divulgada e tantas vezes demonstrada.

Agradeço as crianças dessa família Ricardo, Beatriz, Rafael, Samuel, Daniel, Isabela e Felipe, para quem sei que sou exemplo, pelo estímulo em fazer o melhor.

Ao Henrique, meu grande parceiro, pelo incentivo, pela força nas tardes de domingo em que estudou ao meu lado, pelos conselhos e reflexões sobre a elaboração desta tese e sobre a minha vida profissional, pela serenidade que me transmite nos momentos difíceis.

Ao meu orientador Paulo Manuel Pêgo Fernandes, por quem tenho muita admiração, que com muita disposição me acolheu no laboratório e com muita paciência e sabedoria me ajudou a seguir o caminho da pesquisa, pela oportunidade de realizar este trabalho e pelo privilégio de trabalharmos juntos.

À minha primeira aluna de iniciação e atual parceira no trabalho, Natalia A. Nepomuceno, por toda dedicação e auxílio em todas as etapas deste trabalho, pela amizade e alegria que me incentivaram e, é claro pelas mais de 3.120 gavagens! 
Ao amigo Marcelo Zeviani por me ensinar, com muita paciência, a cirurgia de secção e anastomose brônquica.

Ao amigo Aristides pela disposição em ajudar, por me guiar na análise estatística, pelas conversas e reflexões sobre a nossa profissão.

À amiga Petra, por me trazer ao Incor pela primeira vez, o que me possibilitou conhecer o Prof. Paulo Pêgo e a linha de Pesquisa do LIM61.

Aos funcionários da disciplina de Cirurgia Torácica: Márcia, Sônia, Rosangela, Roseli e Eliana pelo apoio, pelos conselhos e por me possibilitarem infraestrutura para realização deste trabalho.

Aos amigos contemporâneos da pós-graduação Artur Eugênio Azevedo, Arteiro Menezes, Alessandro Wassum Mariani, Israel Lopes Medeiros, Lucas Fernades, Paula Roberta e Viviane Paes pelas conversas, sugestões e por me ensinarem tanto sobre a pesquisa de cada um.

Aos amigos e colaboradores das pesquisas do LIM61 Marcos N. Samano, Eduardo de Campos Werebe, Mauro Canzian, Paulo Francisco G. Cardoso, por todo auxílio e pelo trabalho em conjunto na elaboração e desenvolvimento dos protocolos do laboratório.

Aos funcionários da Divisão Cirúrgica Experimental, Suely, Liliane, Nelsinho, Richard, Elenice, Eduardo, Mônica, Dário, Vicente e Pedro, pelo apoio e pela disposição em ajudar. 
Ao grupo de Defesa Pulmonar, de maneira especial a Mariângela Machionne, Vivien Piccin, Kelly, Regiani Carvalho Oliveira e Naomi Kondo Nakagawa pelas reuniões do grupo, sempre enriquecedoras.

Aos amigos do Lim 05 e 20 : Jose Mara, Juliana Andrietta, Ana Mieli, Eliane Tigre, Dolores Rivero, Heloisa Bueno, Adriana Pires, Beatriz, Lúcia Garcia Bueno, Luis Afonso, David e Ivandir por todo apoio durante o período de execução desta tese.

As queridas e sempre muito atenciosas Neusa, Juliana e Eva do Programa de Pós-graduação em Cirurgia Torácica e Cardiovascular, por todo apoio prestado aos alunos do programa.

Aos membros da Comissão de pós-graduação, de maneira especial ao professor Fabio Jatene e ao professor Luis Felipe Moreira pelo empenho em promover o crescimento do programa de pós-graduação em cirurgia torácica e cardiovascular da USP. As reuniões da comissão de pós-graduação foram momentos enriquecedores na minha vida acadêmica. Como representante discente, tive a oportunidade de observar a clareza e a justiça que regem a tomada de decisões dentro do nosso programa.

Muito Obrigada! 
Esta tese está de acordo com as seguintes normas, em vigor no momento desta publicação:

Referências: adaptado de International Commitee of Medical Journals Editors (Vancouver)

Universidade de São Paulo. Faculdade de Medicina. Serviço de Biblioteca e Documentação. Guia de apresentação de dissertações, teses.

Elaborado por Annaliese Carneiro Carneiro da Cunha, Maria Julia de A. L. Freddi, Maria F. Crestana, Marinalva de Souza Aragão, Suely Campos Cardoso, Valéria Vilhena. $2^{a}$. ed. São Paulo: Serviço de Biblioteca e Documentação; 2005.

Abreviatturs dos títulos dos periódicos de acordo com List of Journals Indexed in Index Medicus. 


\section{Sumário}

Lista de Tabelas

Lista de Figuras

Lista de Gráficos

Resumo

Summary

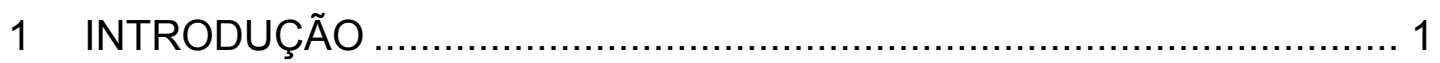

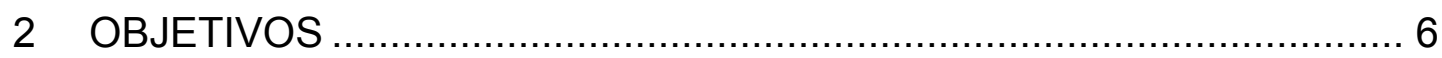

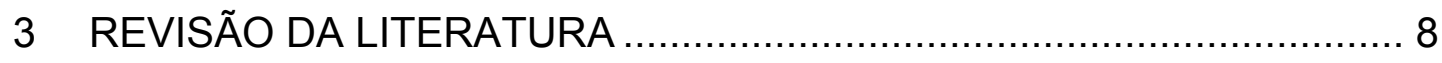

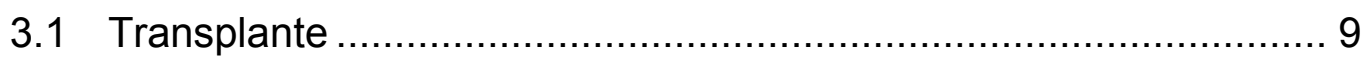

3.1.1 Histórico do Transplante........................................... 9

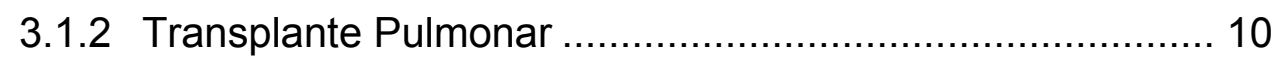

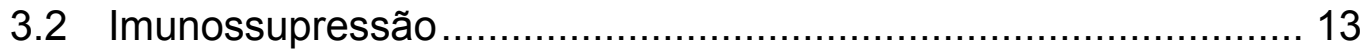

3.2.1 Imunologia e Transplante .......................................... 13

3.2.2 Protocolos de Imunossupressão ................................. 14

3.3 Corticoterapia.......................................................... 17

3.3.1 Histórico da Corticoterapia ..................................... 17

3.3.2 Mecanismos de ação dos Corticosteróides ...................... 18

3.3.3 Prednisona .......................................................... 20

3.3.4 Corticoterapia e Transplante ................................. 21

3.4 Depuração Mucociliar ...................................................... 22

3.4.1 Muco.......................................................... 25

3.4.2 Batimento Ciliar ............................................... 27

3.4.3 Acoplamento Mucociliar......................................... 28

3.4.4 Transplante Pulmonar e Depuração Mucociliar................. 30 


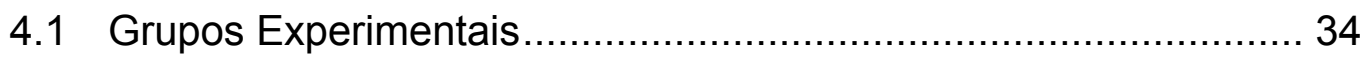

4.1.1 Formação das chaves de comparação intergrupos ............. 36

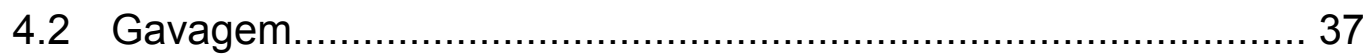

4.3 Seç̧ão e Anastomose Brônquica …………………………...... 37

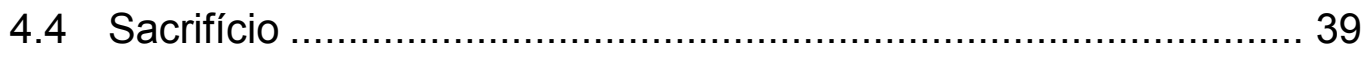

4.5 Transportabilidade do muco in vitro ............................................ 39

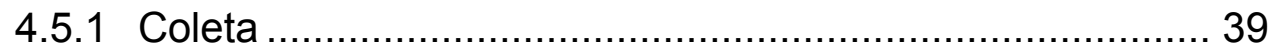

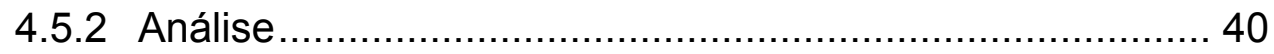

4.6 Freqüência de Batimento Ciliar in situ........................................ 43

4.7 Velocidade de Transporte Mucociliar in situ ............................... 44

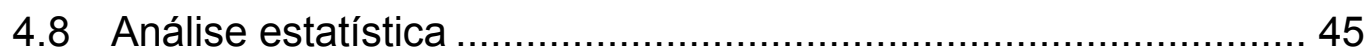

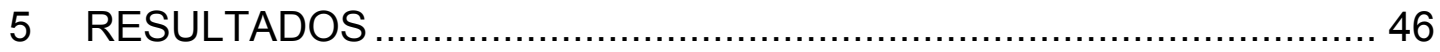

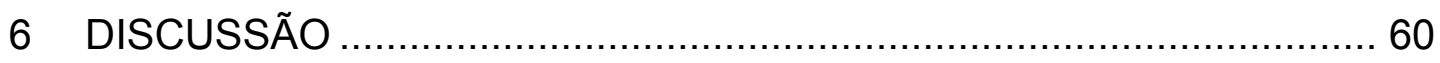

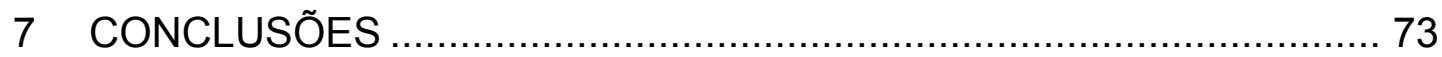

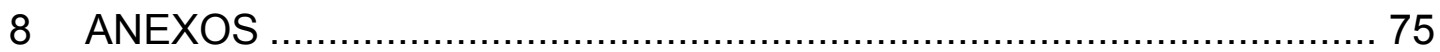

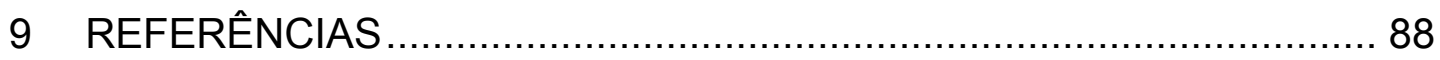


Esta pesquisa recebeu subsídio financeriro

Fapesp - Auxilio Pesquisa Regular - Porcesso no. 2007/50090-5

Capes- Bolsa de Doutorado 


\section{Lista de Tabelas}

Tabela 1. Drogas imunossupressoras em uso clínico 16

Tabela 2. Potência relativa dos glicocorticóides sistêmicos .21

Tabela 3. Média e desvio-padrão da FBC $(\mathrm{Hz})$ dos grupos submetidos ou não à terapia com Prednisona

Tabela 4. Média e desvio-padrão da VTMC ( $\mathrm{mm} / \mathrm{min})$ dos grupos submetidos ou não à terapia com Prednisona

Tabela 5. Média e desvio-padrão do FBC (Hertz) dos grupos submetidos ou não à cirurgia de secção e anastomose brônquica .53

Tabela 6. Média e desvio-padrão do VTMC $(\mathrm{mm} / \mathrm{min})$ dos grupos submetidos ou não à cirurgia de secção e anastomose brônquica .55

Tabela 7. Média e desvio-padrão da TM dos grupos submetidos ou não à cirurgia de secção e anastomose brônquica 


\section{Lista de Figuras}

Figura 1. Mecanismo de ação dos glicocorticóides. Os glicocorticóidesse difundem para o citoplasma celular e provocam a dimerização dos receptores glicocorticóides e sua translocação para o núcleo celular onde atuam na regulação da expressão dos genes alvos.

Figura 2. Fotomicrografia do epitélio respiratório destacando as células ciliadas e as células caliciformes

Figura 3. Elétron-micrografia de células ciliadas. Observe os microtúbulos dos cílios cortados transversal e obliquamente. No ápice das células, os corpúsculos basais, estruturas em forma de $U$, onde se inserem os cílios. Abaixo, um acúmulo de mitocôndrias. As setas indicam um complexo juncional entre duas células vizinhas. Aumento de aproximadamente $10000 \times \ldots 28$

Figura 4. Desenho esquemático do TMC com apresentação das camadas de muco (gel e sol), cílios, zona de penetração dos cílios na camada gel do muco, e direção do movimento ciliar para região de orofaringe

Figura 5. Dissecação do brônquio e ligadura com fio de algodão .38

Figura 6. Anastomose do Brônquio esquerdo. Aumento de $8 \times \mathrm{X}$. PM = porção membranosa $\mathrm{CP}=$ coto proximal; $\mathrm{CD}=$ coto distal.

Figura 7. Coleta de amostra de muco do brônquio 
Figura 8. Equipamentos utilizados para medida da transportabilidade das amostras de muco em palato de rã. $\mathrm{NU}=$ nebulizador ultrassônico; $\mathrm{CA}$ = câmara acrílica; $\mathrm{EM}$ = estereomicroscópio; $\mathrm{OR}=$ ocular reticulada

Figura 9. Representação do palato de rã sendo visualizada através de ocular reticulada

Figura 10.Equipamentos utilizados para medida da freqüência de batimento ciliar e da velocidade de transporte mucociliar. $\mathrm{CF}=$ câmera filmadora; ES = estroboscópio; FO = fibra óptica; MF = monitor de freqüência; $\mathrm{MI}=$ monitor de imagem; $\mathrm{MO}=$ microscópio óptico; OR = ocular reticulada. 


\section{Lista de Gráficos}

Gráfico 1. Velocidade de Transporte Mucociliar dos animais tratados com diferentes doses de prednisona P1, P2, P3 ou com solução fisiológica $0,9 \%$.

Gráfico 2. Transportabilidade do muco dos animais tratados com diferentes doses de prednisona P1, P2, P3 ou com solução fisiológica 0,9\% Grupo Sal.

Gráfico 3. Freqüência de batimento dos grupos submetidos à cirurgia de secção e anastomose brônquica e dos não submetidos à cirurgia.

Gráfico 4. Freqüência de batimento ciliar dos grupos submetidos à cirurgia de secção e anastomose brônquica e ao tratamento com prednisona.

Gráfico 5. Velocidade de Transporte dos grupos submetidos à cirurgia de secção e anastomose brônquica e dos não submetidos à cirurgia.

Gráfico 6. Velocidade de transporte mucociliar dos grupos submetidos à cirurgia de secção e anastomose brônquica e ao tratamento com prednisona.

Gráfico 7. Transportabilidade do muco dos grupos submetidos à cirurgia de secção e anastomose brônquica e dos não submetidos à cirurgia.

Gráfico 8. Transportabilidade do muco "in vitro" dos grupos submetidos à cirurgia de secção e anastomose brônquica e ao tratamento com prednisona. 


\section{Resumo}

BRAGA KA. Estudo dos efeitos da prednisona sobre o sistema mucociliar de ratos [Tese]. São Paulo: Faculdade de Medicina, Universidade de São Paulo; 2010. 100p.

INTRODUÇÃO: As infecções pulmonares constituem uma das principais causas de morbidade e mortalidade após o transplante pulmonar. $O$ transplante expõe a árvore brônquica a uma série de condições, como à lesão de secção e anastomose brônquica e à ação dos imunossupressores, alterando os componentes do epitélio mucociliar. O sistema mucociliar presente nas vias aéreas do sistema respiratório é o principal mecanismo de defesa do trato respiratório, assim a influência de drogas neste sistema precisa ser investigada. A prednisona é um importante corticosteróide usado após o transplante de pulmão, no entanto seu uso pode estar associado ao aumento da mortalidade no período pós por complicações como baixa cicatrização e infecções. Desta forma, o objetivo deste estudo foi avaliar os efeitos da secção brônquica e da terapia com prednisona na depuração mucociliar. MÉTODOS: Foram utilizados 180 ratos machos Wistar distribuídos em 6 grupos (P1, P2, P3, ScP2, ScSal e Sal). Os animais dos grupos P1, P2 e P3 receberam diferentes doses de prednisona $(0,625,1,25$ e $2,5 \mathrm{mg} / \mathrm{kg} / \mathrm{dia})$; os do grupo ScP2 foram submetidos à cirurgia de secção e anastomose brônquica e terapia com $1.25 \mathrm{mg} / \mathrm{kg} / \mathrm{dia}$ de prednisona; do grupo ScSal foram submetidos à cirurgia de secção e anastomose brônquica e gavagem diária de solução fisiológica; por fim, os animais do grupo Sal receberam gavagem de solução fisiológica. Após o período de tratamento (7, 15 ou 30 dias), os animais foram sacrificados, e as medidas de freqüência de batimento ciliar (FBC), velocidade de transporte mucociliar (VTMC) e transportabilidade do muco (TM) coletadas. Para avaliar os efeitos da droga realizamos a análise estatística comparativa entre os grupos P1, P2, P3 e Sal. Para avaliar a possível interação da droga com o procedimento cirúrgico comparamos os grupos ScP2, ScSal e P2. RESULTADOS: A administração das diferentes doses de prednisona estudadas prejudicaram a TM e a dosagem mais alta (P3) diminuiu a VTMC. Os animais submetidos à secção e anastomose brônquica mostraram redução significativa de VTMC e FBC após 7 e 15 dias da cirurgia $(p<0.001)$ Observamos a recuperação desses parâmetros após 30 dias do procedimento cirúrgico. A droga melhorou a TM dos animais submetidos à secção e anastomose brônquica $(p<0,02)$. CONCLUSÕES: Altas dosagens de prednisona prejudicam a depuração mucociliar. A terapia com prednisona associada à cirurgia de secção e anastomose brônquica não altera a depuração mucociliar visto que, apesar de melhorar a transportabilidade do muco, a freqüência de batimento ciliar e a velocidade de transporte mucociliar não são influenciadas.

Descritores: Prednisona, Depuração mucociliar, Brônquios, Transplante de pulmão, Imunossupressão. 


\section{Summary}

BRAGA KAO. Effects of prednisone on mucociliary system of rats [Thesis]. São Paulo: "Faculdade de Medicina, Universidade de São Paulo"; 2010, 100p.

INTRODUCTION: Infections have been and still are the major cause of morbidity and mortality after lung transplantation. Since mucociliary clearance (MCC) plays an important role on the human defense mechanism, the influence of drugs on MCC of patients submitted to lung transplantation must be examined. Prednisone is the most important corticosteroid used after lung transplantation. The aim of this study was to evaluate the effects of bronchial transection and prednisone therapy $(P)$ on mucociliary clearance. METHODS: 180 rats were assigned to 6 groups (P1, P2, P3, ScSal, e Sal) according to surgical procedure or drug therapy: P1 $(0.625 \mathrm{mg} / \mathrm{kg} / \mathrm{day}), \mathrm{P} 2$ (1.25 $\mathrm{mg} / \mathrm{kg} /$ day), P3 $(2.5 \mathrm{mg} / \mathrm{kg} /$ day), ScP2 (bronchial section and reanastomosis $+1.25 \mathrm{mg} / \mathrm{kg} /$ day ), Sal (saline solution $2 \mathrm{ml} /$ day) and ScSal (bronchial section + saline solution $2 \mathrm{ml} /$ day). After 7,15 or 30 days they were killed and lungs were removed from thoracic cavity. Mucociliary transport velocity (MCTV), ciliary beting frequency (CBF) and mucus transportability (MT) were evaluated. RESULTS: The administration of different doses of prednisone studied harmed MT and the highest dosage (P3) decreased MCTV. FBC and MCTV was significantly impaired 7 and 15 days after bronchial transection and reanastomosis $(p<0.001)$, but they showed a partial recovery on the 30th day after surgery procedure. Prednisone therapy improved MT after surgery procedure $(p<0,02)$. CONCLUSION: High dosages of prednisone affect mucociliary clearance. The Prednisone therapy after section and reanastomosis surgery not affect mucociliary clearance since, despite improving MT, the CBF and MCTV are not influenced.

Descriptors: Prednisone, Mucociliary clearance, Bronchi, Lung transplantation, Immunosuppression. 


\section{INTRODUÇão}


O sistema mucociliar presente no sistema respiratório funciona basicamente pela ação conjunta de dois de seus componentes: muco e cílios. O transporte mucociliar normal depende de vários fatores que se interrelacionam como o epitélio intacto, batimento ciliar coordenado, composição e viscoelasticidade adequada do muco, tamanho da camada periciliar.

O transplante pulmonar (TP) expõe a árvore brônquica a uma série de eventos como anestesia, ventilação mecânica e imunossupressão que podem alterar os componentes do epitélio mucociliar (Aeba et al.,1993).

Dentre os fatores envolvidos na cirurgia de transplante pulmonar, a secção brônquica parece ter um papel importante no quadro geral de complicações pós-operatórias. Um grande problema após o transplante está relacionado à cicatrização bronquial deficiente, provocando estenose e deiscência (Samano et al., 2009). Estudos relatam que, após o transplante, o transporte mucociliar (TMC) e a freqüência de batimento ciliar (FBC) estão diminuídos e que há um aumento na rigidez do muco (Veale et al., 1993; Tomkiewicz et al., 1995; Pazetti et al., 2008).

A diminuição do TMC leva a um quadro de retenção de muco contribuindo com quadros de infecção pulmonar. Essa condição, associada aos protocolos de imunossupressão e ao fato de que o pulmão é um órgão transplantado exposto ao ar ambiente faz com que os quadros de infecção sejam freqüentes nesses pacientes. Bactérias e fungos são as principais 
causas de infecções durante o primeiro mês do período pós-operatório, enquanto as infecções virais são mais prevalentes no $2^{\circ}$ e $3^{\circ}$ mês pósoperatório (Krishnam et al., 2005).

Outro fator de extrema relevância associado ao aumento da incidência de infecções nesses pacientes diz respeito à imunossupressão. Há alguns anos, os protocolos de imunossupressão após o transplante de órgãos eram restritos e muitas vezes limitados à administração empírica e não monitorada de azatioprina e prednisona. A introdução de múltiplas drogas na década de 90 aumentou o sucesso no transplante da maioria dos órgãos sólidos, com efeitos mais específicos e monitorados (Dong et al., 1999; Fan et al., 2009). No TP, a imunossupressão é baseada em um esquema tríplice, que associa fármacos inibidores da produção de IL-2 (ciclosporina ou tacrolimus), fármacos inibidores da síntese de purinas ou pirimidinas (Azatioprina ou Micofenolato de Mofetila), e fármacos que inibem a expressão de genes de citocinas, como a prednisona (Hertz et al., 2008; Cristie et al., 2009).

Além da modulação da resposta imunológica adaptativa, sabemos que os imunossupressores podem prejudicar elementos da resposta inata, entre eles, a depuração mucociliar.

O Laboratório de Pesquisa em Cirurgia Torácica da FMUSP (LIM 61), tem como uma de suas principais linhas de pesquisa o estudo das alterações na depuração mucociliar pós transplante pulmonar. Estudos realizados nesse laboratório mostram que tanto a lesão brônquica quanto a administração de imunossupressores, como a ciclosporina e azatioprina, 
prejudicam o TMC (Rivero et al., 2001; Xavier et al., 2007; Pazetti et al., 2007; Pazetti et al., 2008). Num primeiro estudo foram avaliados os efeitos da cirurgia de secção e anastomose brônquica unilateral na depuração mucociliar, sendo observado prejuízo dessa função nos brônquios submetidos ao procedimento cirúrgico (Rivero et al., 2001). Tal prejuízo foi atribuído a alterações nas propriedades viscoelásticas do muco produzido na região brônquica lesionada. Esse mesmo grupo mostrou que a azatioprina diminui a velocidade de transporte mucociliar nos animais avaliados 7 dias após o procedimento cirúrgico com recuperação nos animais avaliados após 30 dias da cirurgia (Fernandes et al., 2008). Apesar do prejuízo no TMC, esse estudo verificou melhora nas propriedades viscoelásticas do muco dos animais submetidos à cirurgia de secção e anastomose brônquica e tratados com azatioprina. Uma série de três estudos avaliou os efeitos da ciclosporina na depuração mucociliar (Xavier et al., 2007; Pazetti et al., 2007; Pazetti et al., 2008). Utilizando o modelo cirúrgico de secção e anastomose brônquica foi verificado que a ciclosporina diminui a velocidade de transporte mucociliar (VTMC), como resultado do prejuízo tanto da freqüência de batimento ciliar (FBC) quanto da transportabilidade do muco (TM), além de redução da secreção de muco (Pazetti et al., 2007; Pazetti et al., 2008). Observou-se que a ciclosporina exerce efeito sinérgico quando associada à lesão de secção brônquica, diminuindo a depuração mucociliar. Utilizando modelo de transplante pulmonar em ratos, verificou-se ainda que a ciclosporina melhora a depuração mucociliar nos animais transplantados, provavelmente pela diminuição da resposta imunológica ao enxerto (Xavier et al., 2007). 
São escassos na literatura trabalhos relacionados aos efeitos dos corticosteróides sistêmicos no aparelho mucociliar. Investigações in vitro que avaliaram a influência de corticóides no TMC mostraram que a prednisolona aumenta a produção de muco e corticóides tópicos como a budesonida diminuem a FBC na mucosa respiratória (Maron et al.,1984; Duchateau et al., 1986; Hofmann et al., 1998).

McAnally et al. (2006), avaliaram os riscos da utilização de prednisona em pacientes transplantados e mostraram que os índices de sobrevida foram muito melhores nos pacientes que receberam doses $<0,42 \mathrm{mg} / \mathrm{kg} / \mathrm{m}^{2}$ por dia do que os que receberam doses $>0,42 \mathrm{mg} / \mathrm{kg} / \mathrm{m}^{2}$ por dia. As mortes no período pós-operatório podem ter sido induzidas pelos esteróides por complicações como baixa cicatrização e infecções.

Assim, nos propusemos a dar continuidade a essa importante linha de pesquisa, visando contribuir para o entendimento da ação de outra droga, a prednisona, comumente utilizada na prática clínica. 
2 OBJETIVOS 
O presente trabalho teve como objetivos:

1. Avaliar os efeitos da terapia com prednisona na depuração mucociliar.

2. Avaliar os efeitos resultantes da associação entre lesão de secção brônquica e a terapia com prednisona na depuração mucociliar. 
3 REVISÃO DA LITERATURA 


\subsection{Transplante}

\subsubsection{Histórico do Transplante}

O transplante post mortem corresponde à retirada de órgãos, tecidos ou partes de corpo humano de cadáver para ser implantado em um receptor vivo. Essa técnica foi um dos maiores avanços da medicina do século 20 , constituindo uma terapêutica eficaz para pacientes com doença incapacitante, progressiva e em estágio final. No início dessa atividade, em humanos, os resultados eram limitados e a sobrevida muito baixa. O transplante renal foi o primeiro dos procedimentos de transplante de órgãos com sucesso. Ocorreu nos Estados Unidos no ano de 1954, quando o médico cirurgião Joseph Murray fez um transplante de rim entre irmãos gêmeos idênticos (Muray et al., 1976). Outro momento histórico para o transplante, sem dúvidas, foi marcado por Christian Barnard em 1967, na África do Sul, que realizou o primeiro transplante de coração. O transplante realizado por Christiam Barnard foi em um paciente de 54 anos portador de uma severa doença nas artérias coronárias e de múltiplos infartos do miocárdio e o doador foi uma mulher de 24 anos com morte encefálica. O transplante de coração trouxe a tona uma série de discussões e conflitos na época, já que ia contrapor um conceito que levava em conta a parada 
cardíaca para definição da morte de um indivíduo. O conceito relativo ao momento da morte sofreu algumas mudanças ao longo dos anos, sendo fundamental o estabelecimento do conceito de morte encefálica para realização da maioria dos transplantes post-morten.

Nos anos seguintes novos relatos foram feitos, entretanto a rejeição limitava os resultados, diminuindo a sobrevida dos pacientes. Sem dúvidas, o marco inicial do progresso nos resultados dos transplantes ocorreu na década de 80 , com o desenvolvimento de potentes imunossupressores, particularmente a ciclosporina A. Esses medicamentos trouxeram grande benefício para o sucesso das cirurgias de transplante, aumentando a taxa de sobrevida logo no primeiro ano (Bier et al., 1993; Dong et al., 1999; Fan et al., 2009). Além disso, contribuíram para esse progresso a implementação de leis reguladoras da atividade, o aprimoramento das técnicas cirúrgicas, o desenvolvimento de exames imunológicos para seleção de doador, o conhecimento mais profundo a respeito dos mecanismos de rejeição, entre outros. Os resultados positivos estimularam o desenvolvimento de centros de excelência em todo o mundo.

\subsubsection{Transplante Pulmonar}

O primeiro TP em humanos descrito na literatura foi realizado por James Hardy em 1963 (Hardy, 1964). O paciente sobreviveu 18 dias e sua morte foi atribuída a problemas renais e ao seu estado de desnutrição. Este objetivo foi alcançado após Hardy acumular experiência em protocolos 
com cães. Este esforço pioneiro estabeleceu uma técnica viável e demonstrou que o transplante pulmonar poderia funcionar em humanos. Nos vinte anos seguintes não houve muitos progressos (Nelems et al., 1980). O sucesso nessa modalidade terapêutica só foi alcançado em 1983, pelo grupo de Toronto (Toronto Lung Transplant Group). Os avanços obtidos ao longo dos anos transformaram o TP em um método terapêutico consolidado, com índices de sobrevida de 60\% após 5 anos (Hartgan e Pedoto, 2005).

No Brasil, o primeiro TP foi realizado no ano de 1989 (Camargo et al., 1990). Nos últimos anos, temos observado um aumento no número de transplantes realizados neste país, assim como na qualidade dos resultados (Jatene e Pêgo Fernandes, 2008). Em 2008, foram realizados 53 transplantes de pulmão o que resulta em $15,2 \%$ a mais que no ano anterior. Nesse período o país apresentava apenas 4 equipes de transplante pulmonar ativas. Atualmente a Santa Casa de Porto Alegre e o Instituto do Coração em São Paulo se destacam como os maiores centros transplantadores de pulmão no cenário nacional. O Instituto do Coração implementou definitivamente seu programa de transplante pulmonar em 2000 e tem mostrado um crescimento progressivo no número de receptores, transplantes realizados e sobrevida média dos pacientes.

O transplante pulmonar é indicado aos pacientes que esgotam os recursos terapêuticos clínicos convencionais sem resultados satisfatórios no curso de suas pneumopatias (Studen et al., 2004; Miranda et al., 2005). A DPOC (Doença Pulmonar Obstrutiva Crônica) ainda é a maior responsável pelas indicações ao transplante pulmonar, com 36\% do total de indicações, 
seguida pela fibrose pulmonar idiopática (20\%), fibrose cística (16\%), enfisema por deficiência de alfa-1 antitripsina (7.6\%) e hipertensão arterial pulmonar idiopática (3.5\%) (Christie et al., 2005). Os tipos de transplante disponíveis são: transplante de pulmão unilateral, transplante de pulmão bilateral, transplante lobar intervivos e transplante combinado coraçãopulmão. Atualmente, essa modalidade terapêutica representa melhora substancial na qualidade de vida e aumento de sobrevida.

A International Society For Heart and Lung Transplantation (ISHLT) publicou resultados de mais de 29.000 transplantes de pulmão realizados em mais de 200 centros espalhados pelo mundo, mostrando que a sobrevida tem melhorado ao longo das décadas devido aos avanços nas soluções de preservação de órgãos, nas técnicas cirúrgicas, no manejo pós-operatório intensivo, no controle e tratamento das infecções e nos esquemas de imunossupressão (Hertz et al., 2008).

Apesar dos avanços, alguns fatores limitam o sucesso do TP, como a escassez de órgãos viáveis para o transplante, dificuldades na preservação do órgão, alta mortalidade dos pacientes na fila de espera e baixa sobrevida dos transplantados, quando comparado ao transplante de outros órgãos sólidos (Jatene e Pêgo-Fernandes, 2008; Pêgo-Fernandes et al, 2006).

A sobrevida média, para os receptores, é de aproximadamente $90 \%$ nos primeiros 3 meses, $78 \%$ em 1 ano, $63 \%$ em 3 anos, $51 \%$ em 5 anos e $28 \%$ em 10 anos. Entre as causas de morte mais freqüentes nos primeiros 30 dias, após o transplante de pulmão, estão a falha do enxerto, infecções não associadas ao citomegalovírus (CMV), complicações cardiovasculares e problemas associados à técnica cirúrgica (Hertz et al., 2008). 
Assim, principais complicações após o TP relacionam-se ao manejo do binômio rejeição/infecção. No primeiro ano, os episódios infecciosos constituem a principal causa de óbito neste grupo de pacientes. O órgão enxertado é o principal foco dos episódios infecciosos e as pneumonias bacterianas são fatores importantes de morbi-mortalidade nos períodos precoce e tardio do pós-operatório. Chaparro et al. (2001), observaram que as pneumonias bacterianas no período pós-transplante apresentam a $P$. aeruginosa em $33 \%$ casos e a sua colonização em vias aéreas no período pré-transplante como fator associado às pneumonias no pós-operatório em pacientes com doença supurativa. Após o primeiro ano, a bronquiolite obliterante (BO), representando a forma de rejeição crônica, e as infecções, não associadas ao CMV, são as causas predominantes de morte. Entre outras mais tardias, destacam-se as causas de morte por neoplasia e por doenças cardiovasculares (Hertz et al., 2008).

\subsection{Imunossupressão}

\subsubsection{Imunologia e Transplante}

Uma das maiores dificuldades para a implementação do transplante de órgãos como rotina de tratamento de pacientes consiste na possibilidade de rejeição do enxerto em decorrência da resposta imune do receptor ao tecido doado. Assim, para o desenvolvimento deste tipo de tratamento foi 
essencial o conhecimento dos mecanismos de rejeição ao aloenxerto, o desenvolvimento de novas drogas imunossupressoras além de progressos na seleção dos doadores e receptores.

Paul Ehrlich em 1906 e Aléxis Carrel em 1910 foram os primeiros a atribuir causas biológicas para a rejeição. A descoberta dos grupos sanguíneos na década de 1920 pelo vienense Karl Landsteiner, e a descrição da natureza imunológica da rejeição a enxertos cutâneos por Peter Medawar lançaram as bases para o estudo dos fenômenos imunológicos envolvidos na rejeição (Roitt, 1999).

Desde os primeiros relatos de transplante pulmonar em humanos até a consolidação da técnica como alternativa terapêutica, passaram-se 20 anos em que o principal desafio era o controle da rejeição. Esta falta de progressos provocou um impulso na investigação laboratorial dos aspectos bioquímicos, imunológicos e farmacológicos dos mecanismos de rejeição.

Diversas linhas mostraram que a rejeição é desencadeada através da resposta imune adaptativa relacionada a genes polimórficos localizados em um único cromossomo, o cromossomo 6 , herdados de ambos os pais $\mathrm{e}$ expressos de maneira co-dominante (Bradbury, 1999).

\subsubsection{Protocolos de Imunossupressão}

As drogas imunossupressoras que inibem a atividade ou destroem os linfócitos T são o principal regime de tratamento anti-rejeição. A maioria destes fármacos atua durante a fase de indução da resposta imunológica reduzindo a 
proliferação de linfócitos, embora outros também inibam a fase efetora. Geralmente, a imunossupressão é baseada em um esquema tríplice que associa fármacos inibidores da produção de IL-2 (ciclosporina ou tacrolimus) a fármacos inibidores da síntese de purinas ou pirimidinas (Azatioprina ou Micofenolato de Mofetila) e fármacos que inibem a expressão de citocinas, como a prednisona (Hertz et al., 2008; Cristie et al., 2009).

Até a década de 70 os protocolos de imunossupressão após o transplante de órgãos eram mais restritos e muitas vezes limitados à administração empírica e não monitorada de azatioprina e prednisona. A azatioprina tem atuação citotóxica sobre células em divisão mitótica, por isso inibe a proliferação clonal durante a fase de indução da resposta imunológica. No entanto, a toxicidade associada a essa droga leva a depressão da medula óssea, hepatoxicidade, provoca náuseas, vômito e erupções cutâneas. Os agentes antiinflamatórios mais potentes disponíveis são os corticóides, como a prednisona. Seu emprego foi estabelecido desde os primórdios do transplante e seu modo de ação será discutido no próximo item.

Em 1972, a descoberta da ciclosporina foi crucial para o desenvolvimento do transplante. A ciclosporina, diferentemente dos outros imunossupressores não apresenta citotoxicidade e atualmente constitui o mais importante agente imunossupressor utilizado pós-transplante. Trata-se de um polipeptídeo, derivado de duas espécies de fungos (Tolyplocadium inflatum e Cylindrocarpon lucidum), que bloqueia a transdução de sinais e impede a produção de interleucina (IL-2) e interferon pelos linfócitos T (Caine et al., 1979; Kalan et al., 1983). Atualmente, uma série de imunossupressores 
específicos está disponível no mercado e são escolhidos de acordo com o período pós-operatório, tipo de rejeição e evolução do transplantado. $\mathrm{Na}$ tabela1 estão listados os principais fármacos imunossupressores e seus mecanismos de ação.

Tabela 1. Drogas imunossupressoras em uso clínico (Modificado de Roitt, 1999) DROGA MECANISMO DE AÇÃO

Ciclosporina e Tacrolimus Bloqueiam a produção de citocinas por células T

Azatioprina

Micofenolato de Mofetil

Rapamicina

Corticosteróides

Anticorpo Monoclonal anti-CD3
Bloqueia a proliferação dos precursores de Linfócitos

Bloqueia a proliferação de linfócitos por inibir a síntese do nucleotídio guanina nos linfócitos

Bloqueia a proliferação de linfócitos por inibir a sinalizaçãoda IL-2

Reduzem a inflamação por inibir a secreção de citocinas pelos macrófagos

Depleta as células T por se ligar ao CD3 e promove a fagocitose ou lise mediada por complemento

Os protocolos imunossupressores melhoraram drasticamente a sobrevida do enxerto. No entanto, a imunossupressão necessária para a sobrevivência prolongada do enxerto leva a uma suscetibilidade aumentada ao desenvolvimento de quadros infecciosos e constitui uma importante causa de morbimortalidade após transplantes de órgãos sólidos (Hertz et al., 2008; Cristie et al., 2009). 
No caso do TP sabemos que isso se deve não só a interferência da imunossupressão na resposta adaptativa, mas também a ação dessas drogas em mecanismos de defesa inatos, como é o caso do aparelho mucociliar.

\subsection{Corticoterapia}

\subsubsection{Histórico da Corticoterapia}

A história da corticoterapia tem início por volta de 1855 quando Thomas Addison descreveu pela primeira vez a insuficiência adrenal, o que foi demonstrado em 1856 por Brown-Séquard. Estudos subseqüentes demonstraram relevante controle de sintomas em animais submetidos à adrenalectomia e em pacientes portadores da doença de Addison tratados com estrato do córtex da adrenal (Hartman e Brownell, 1930; Swingle e Pfiffiner, 1930). Em 1935 os americanos Edward Calvin Kendall e Philip Hench isolaram e identificaram a estrutura química de um composto ao qual deram o nome de cortisona recebendo, por este feito o prêmio Nobel em 1950 (Kendall, 1950). Na década de 40 iniciou-se a produção em escala industrial desse composto.

A corticoterapia tem sido utilizada na prática clínica desde 1949, em geral com atuação na regulação de uma série de genes e com efeito total antiinflamatório. Suas indicações se espalham por diversas especialidades médicas incluindo a dermatologia, endocrinologia, oncologia, oftalmologia, cardiopatia e doenças respiratórias. 


\subsubsection{Mecanismos de ação dos Corticosteróides}

Os corticosteróides reduzem a produção de mediadores inflamatórios, incluindo as citocinas, prostaglandinas e óxido nítrico; inibem a migração de células inflamatórias aos locais de inflamação onde impedem a expressão das moléculas de adesão, modulam direta e indiretamente a função das células $B$, reduzem a movimentação de células e fluídos a partir do compartimento intravascular, inibem a resposta proliferativa dos monócitos ao fator de estimulação de colônia e diferenciação em macrófagos e promovem a morte de células linfóides por apoptose.

Os corticosteróides são ésteres lipofílicos que se difundem para o citoplasma celular. O mecanismo clássico de ação dos corticosteróides implica na ligação do esteróide a receptores citosólicos que, dimerizados, dirigem-se ao núcleo celular e se ligam a regiões promotoras do DNA (Figura 1).

Efeitos adversos como a retenção de líquido, ganho de peso, perda mineral óssea e prejuízo no processo de cicatrização limitam a utilização desse tipo de terapia (Damiani et al., 2001; Longui et al., 2007; Charmandari et al., 2004). 


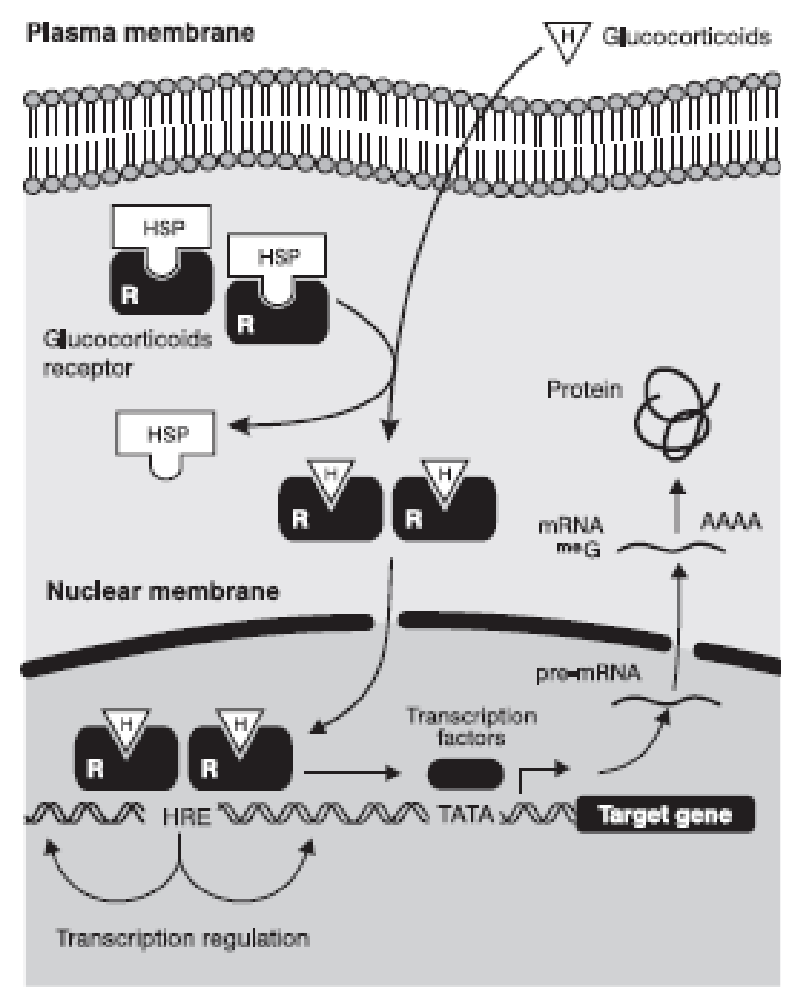

Figura 1. Mecanismo de ação dos glicocorticóides. Os glicocorticóidesse difundem para o citoplasma celular e provocam a dimerização dos receptores glicocorticóides e sua translocação para o núcleo celular onde atuam na regulação da expressão dos genes alvos Fonte: Longui, 2007.

Os corticosteróides naturais são produzidos e liberados na porção externa da adrenal (zona fasciculada) e estão sob o comando adenohipofisário do ACTH (hormônio adeno-corticotrópico) que por sua vez, é controlado pelo hormônio liberador de corticotrofina hipotalâmica (CRF) .

No intuito de se obter esteróides sintéticos de uso terapêutico dotados de potente ação inflamatória, mas com redução de efeitos colaterais indesejáveis, uma série de compostos foram produzidos e testados biologicamente. Um dos mais amplamente utilizados é a prednisona, um análogo sintético da cortisona, quem vem sendo testado desde 1970. 


\subsubsection{Prednisona}

A prednisona é um glicocorticóide sintético, com propriedades antiinflamatórias e imunossupressoras, que tem sido indicada para o tratamento das doenças pulmonares inflamatórias. Consiste em uma pródroga que após a absorção é convertida em um princípio metabolicamente ativo, a prednisolona. É comumente prescrita para o tratamento de doenças endócrinas, osteomusculares, dermatológicas alérgicas, inflamatória intestinal, respiratórias, hematológicas e outras que respondam à terapia com corticosteróides.

Tem sido empregada sistemicamente, é benéfica aos pacientes, promovendo alívio dos sintomas. A dosagem e o período de tratamento são controlados já que efeitos colaterais limitam seu uso (Vondracek e Hemstreet, 2006).

Além da prednisona, são amplamente utilizadas na prática clínica, por sua ação glicocorticóide, a hidrocortisona, dexametasona e a metilprednisolona (Castro et al., 2005; Clarck et al., 2007).

A tabela 2 lista os principais compostos antiinflamatórios de uso clínico e apresenta a potência antiinflamatória, bem como a meia vida biológica desses preparados. Verifica-se que a dexametasona é o composto mais potente, enquanto a hidrocortisona, composto natural, é o de menor potência. 
Tabela 2. Potência relativa dos glicocorticóides sistêmicos

\begin{tabular}{|c|c|c|c|c|}
\hline Corticosteróide & $\begin{array}{l}\text { Meia Vida } \\
\text { Biológica }\end{array}$ & Atividade & $\begin{array}{l}\text { Potência } \\
\text { Relativa }\end{array}$ & $\begin{array}{c}\text { Dose } \\
\text { equivalente }(\mathrm{mg})\end{array}$ \\
\hline Dexametasona & $36-54$ & Longa ação & 25 & 0,75 \\
\hline Prednisona & $18-36$ & $\begin{array}{c}\text { Ação } \\
\text { intermediária }\end{array}$ & 4 & 5,00 \\
\hline Metiprednisolona & $18-36$ & $\begin{array}{c}\text { Ação } \\
\text { intermediária }\end{array}$ & 5 & 4,00 \\
\hline Hidrocortisona & $08-12$ & Curta ação & 1 & 20,00 \\
\hline
\end{tabular}

\subsubsection{Corticoterapia e Transplante}

No início da década de 50, os primeiros estudos sobre as técnicas de transplante pulmonar já relatavam a utilização de corticoterapia ${ }^{52}$. Neptune et al. (1950) documentou uma maior sobrevivência de cães após a associação da corticoterapia ao transplante. Hardy et al., (1963), observou o aumento da sobrevivência de cães administrando azatioprina combinada à hidrocortisona.

No entanto, atualmente, a indicação para transplante pulmonar requer a redução nas doses administradas. Isso porque um grande número de complicações, como baixa cicatrização e aumento na incidência de infecções, são atribuídas à utilização de esteróides durante o período préoperatório (Doherty et al., 1998;'McAnally et al., 2006; Orens et al., 2006; Hertz et al., 2008;). 
O International Guidelines for the Selection of Lung Transplant Candidates, contra-indica doses maiores que $20 \mathrm{mg} / \mathrm{dia}$ a pacientes com prescrição de transplante (Orens et al. 2006). Desde essa publicação, o debate a respeito da dose tolerável de esteróide antes do transplante de pulmão tem aumentado.

\subsection{Depuração Mucociliar}

O tecido pulmonar é constantemente exposto às agressões do meio ambiente, sendo as partes externa e interna deste tecido separadas pela fina barreira alvéolo-capilar que, em média, não ultrapassa $1 \mu \mathrm{m}$ de espessura (Saldiva, 1990). O ar que respiramos constitui uma complexa mistura de gases e material particulado e contém estruturas orgânicas como vírus e bactérias, material inorgânico, além de gases irritantes. Esse material é depositado ao longo do epitélio por impactação inercial, sedimentação gravitacional ou difusão (Kondo et al., 2002). O principal mecanismo de deposição de grandes partículas (maiores que $10 \mu \mathrm{m}$ de diâmetro) nas vias aéreas superiores é a impactação inercial, sobretudo nas regiões de bifurcação. Com a diminuição do fluxo, a sedimentação gravitacional representa o mais importante meio de deposição de partículas nas vias aéreas menores. A deposição por meio dos movimentos brownianos afeta partículas pequenas nos alvéolos. 
Uma série de mecanismos de defesa está envolvida na remoção desses agentes do epitélio respiratório como o TMC, ação de macrófagos, neutrófilos e do sistema linfático. Além do processo de esterilização, o aquecimento e a saturação com vapor de água são condições necessárias para a manutenção da homeostase alveolar. Essas condições começam a ser criadas no início das vias aéreas superiores e terminam nos alvéolos (Carvalho et al., 1999; Kondo et al., 2002).

O sistema respiratório está dividido em porção condutora que recebe e conduz o ar do meio externo para o interior dos alvéolos pulmonares. À medida que o ar avança ao longo das vias aéreas durante a inspiração, encontra um sistema ramificado de túbulos que vai desde a traquéia até os bronquíolos terminais. Essas estruturas são responsáveis por transportar, filtrar, umedecer e aquecer o ar inspirado antes que ele alcance os alvéolos pulmonares. Desta forma, a porção condutora funciona na primeira linha de defesa do sistema respiratório.

Toda a extensão das vias aéreas é recoberta por um epitélio colunar pseudo-estratificado ciliado (epitélio respiratório), lâmina própria (tecido conjuntivo subepitelial) e por um feixe espesso de fibras elásticas. O epitélio respiratório apresenta seis tipos celulares: células caliciformes, células cilíndricas ciliadas, células basais, células em escova, células serosas e células do sistema neuroendócrino difuso.

Ao longo de sua extensão, o trato respiratório apresenta algumas diferenças no que diz respeito à morfologia das células ciliadas, ao número de células produtoras de muco e à densidade de células neuroendócrinas, de forma a atender o padrão funcional de cada micro ambiente. 
O revestimento epitelial apresenta um complexo de depuração local, o TMC, que remove os agentes invasores retidos no muco para a região da orofaringe onde são expectorados ou deglutidos. O TMC é realizado a partir de uma interação harmônica entre as células secretoras e ciliadas que resulta na movimentação do filme de muco que reveste as vias aéreas e conseqüentemente $\mathrm{o}$ material a ele aderido pelas células ciliadas. Conseqüentemente todo material aderido ao muco é eliminado do trato respiratório.

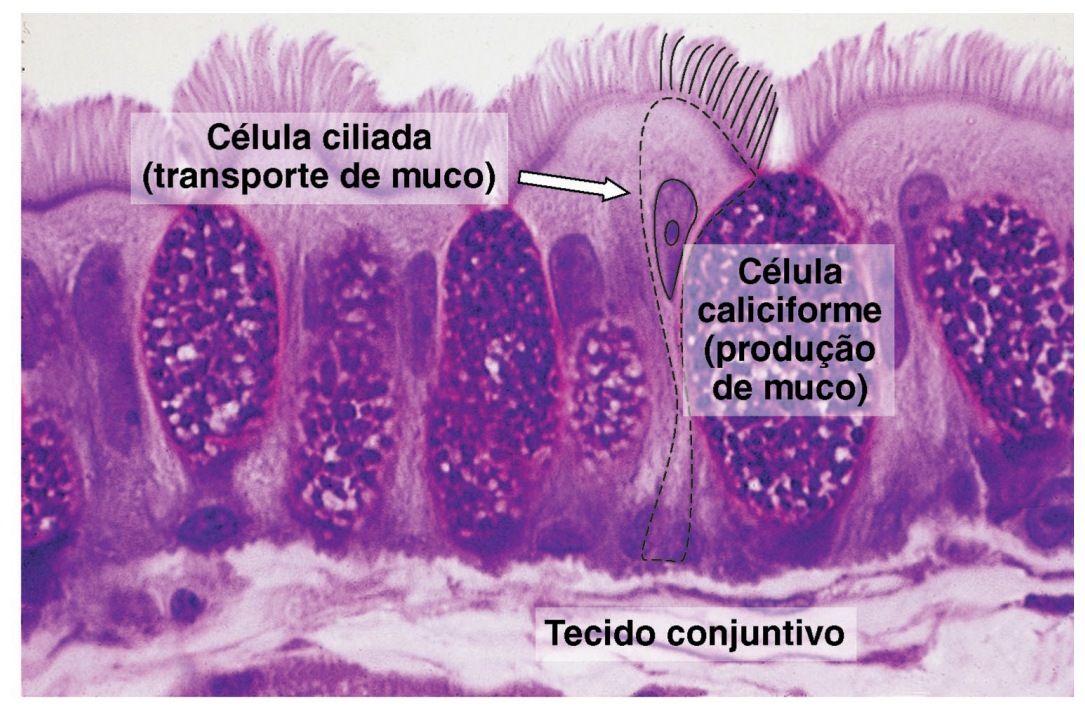

Figura 2. Fotomicrografia do epitélio respiratório destacando as células ciliadas e as células caliciformes

Fonte: Junqueira e Carneiro, 2010.

A eficiência deste sistema depende da integridade e do movimento coordenado dos cílios, das propriedades físicas do muco e da interação entre muco e cílio. A diminuição do transporte mucociliar pode levar à retenção de muco contribuindo com quadros de infecção pulmonar. 


\subsubsection{Muco}

O muco respiratório forma um filme de secreção que cobre quase a totalidade das vias aéreas de condução. Exerce funções de lubrificar e umidificar as vias; proteger o epitélio contra agentes exógenos; promover um ambiente adequado para ao batimento ciliar e diminuir a tensão superficial nas pequenas vias aéreas (Saldiva, 1990).

Este filme de muco apresenta uma camada periciliar aquosa e contínua, denominada hipófase sol e uma segunda camada que repousa sobre a primeira, constituída por um muco mais viscoso e descontínuo (presença de grande quantidade de mucina e proteínas), a epifase gel. Estima-se que $10 \mathrm{ml}$ de muco sejam transportados ao longo do dia em um indivíduo saudável.

O muco respiratório é uma mistura complexa de diferentes secreções que formam um polímero hidrofílico com propriedades visco-elásticas que recobre as vias aéreas. É constituído por aproximadamente 95\% de água e 5\% de compostos orgânicos (aminoácidos, proteínas, glicoproteínas e lipídeos) e íons tais como $\mathrm{Na}^{+}, \mathrm{K}^{+}, \mathrm{Mg}^{+}$e $\mathrm{Ca}^{+}$(Braga, 1990).

O principal dos componentes orgânicos é uma família de macromoléculas denominadas mucinas. São secretadas por células mucosas, caliciformes e secretoras. Estruturalmente as mucinas são glicoproteínas heterogêneas formadas a partir de um filamento protéico central no qual pequenas cadeias laterais de polissacarideos estão ligadas. As mucinas são armazenadas no interior de grânulos das células secretora 
ricas em Ca+ equilibrando as cargas negativas dessa molécula. Na degranulação há alteração na permeabilidade da membrana, colocando em comunicação o espaço intragranular e extracelular, promovendo a entrada de água e saída de Ca+. Com a perda do anteparo de Ca+ ocorre a repulsão das cargas negativas e, portanto a exocitose do conteúdo granular (Verdugo et al., 1980; Lorenzi et al., 1992).

$\mathrm{Na}$ luz das vias aéreas, as mucinas se organizam sob a forma de um biopolímero com propriedades viscoelásticas complexas e bem definidas para uma perfeita interação com o cílio adjacente.

Além das mucinas, estão presentes proteoglicanos, lipídeos, substâncias antioxidante, proteases, antiproteases, tampões, lisozima, peroxidase, lactoferrina, antileucoproteases, albumina, DNA, actina. A principal imunoglobulina no fluído respiratório é a $\lg A$ exercendo um importante papel na prevenção de infecções e reconhecimento de células tumorais.

A composição do muco garante a ele um componente elástico e deformável, importante para seu deslocamento diante da energia transmitida pelo batimento ciliar. Alterações na composição do muco podem influenciar de maneira importante a depuração mucociliar.

O principal mecanismo de controle da secreção nasal é autonômicosendo que a estimulação parassimpática aumenta o volume de secreções (Lund, 1996). 


\subsubsection{Batimento Ciliar}

A célula ciliada tem cerca de 200 cílios, sofrendo influência da idade e posição no trato respiratório. os quais possuem coordenação de batimento ciliar intra e intercelular. A freqüência média de batimento ciliar é da ordem de 10 a $14 \mathrm{~Hz}$. O conjunto de células ciliadas presentes na superfície epitelial do trato respiratório, é responsável pela motilidade do aparelho mucociliar.

Os cílios são prolongamentos citoplasmáticos com estrutura definida no qual o motor é um axonema de tubulina. O axonema de um cílio consiste em nove pares de microtúbulos periféricos que circundam um par de microtúbulos central. Os micrutúbulos são formados por heterodímeros de dineína e tubulina e secundariamente por outras proteínas que se associam através de ligações radiais e circunferenciais, possibilitando o movimento ciliar. 


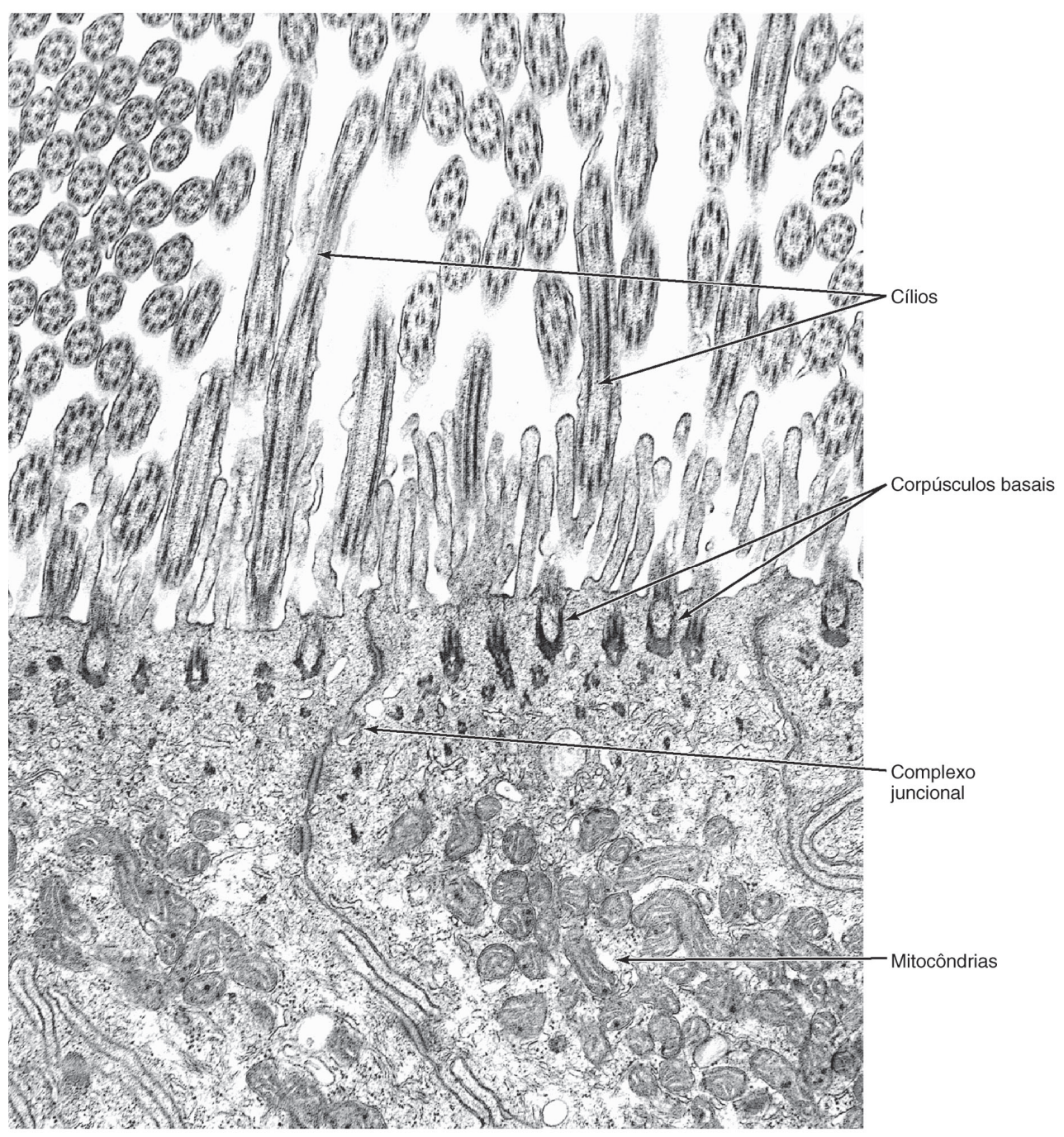

Figura 3. Elétron-micrografia de células ciliadas. Observe os microtúbulos dos cílios cortados transversal e obliquamente. No ápice das células, os corpúsculos basais, estruturas em forma de $U$, onde se inserem os cílios. Abaixo, um acúmulo de mitocôndrias. As setas indicam um complexo juncional entre duas células vizinhas. Aumento de aproximadamente $10000 \mathrm{x}$

Fonte: Junqueira e Carneiro, 2010.

\subsubsection{Acoplamento Mucociliar}

O TMC é realizado graças a interação entre o batimento do cílio e o filme de muco que reveste o epitélio respiratório. 
Essa interação começa na disposição do muco. A camada sol situa-se próxima ao epitélio e possui uma altura próxima à do comprimento dos cílios; a camada gel se localiza acima dessa camada e corresponde ao muco transportado em direção à orofaringe.

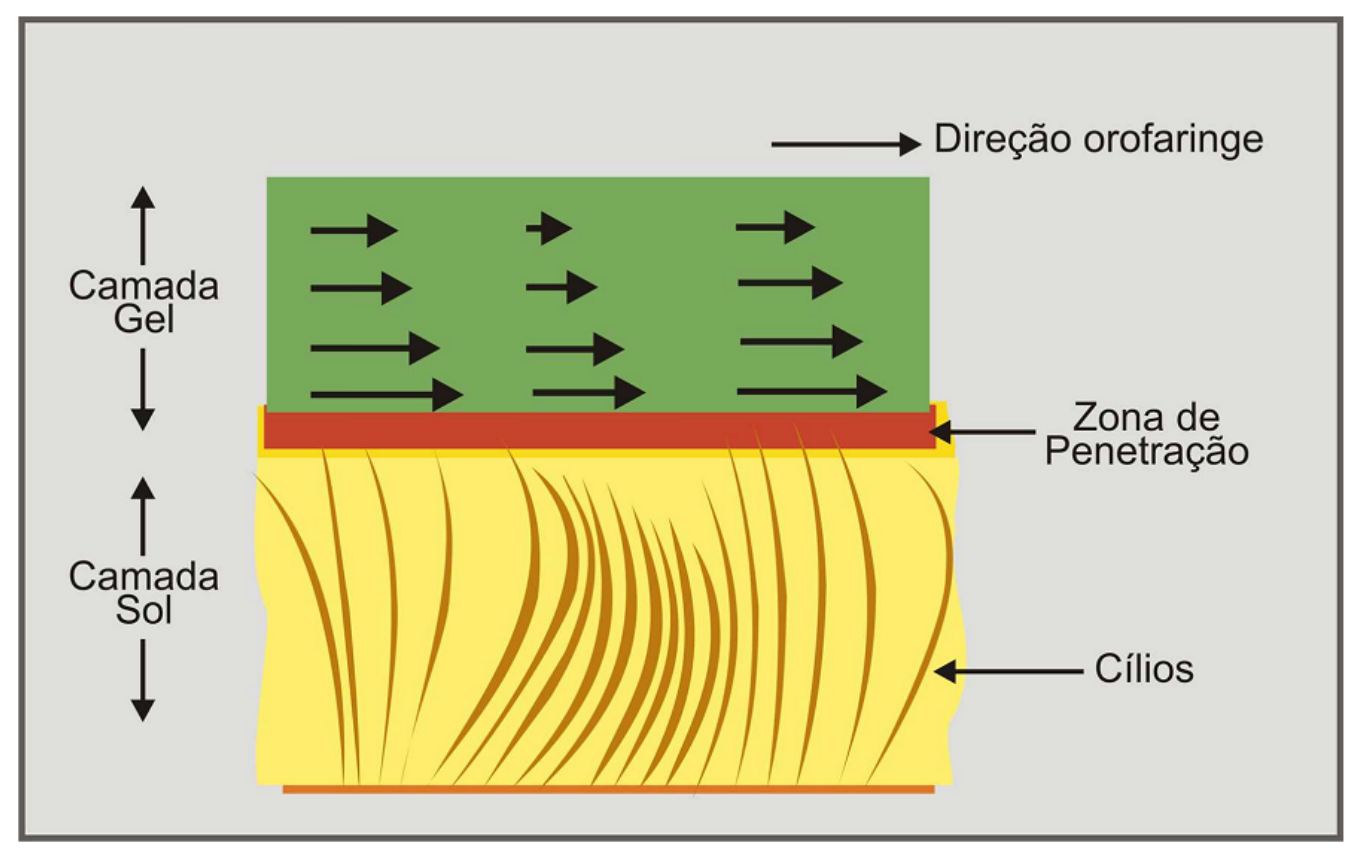

Figura 4. Desenho esquemático do TMC com apresentação das camadas de muco (gel e sol), cílios, zona de penetração dos cílios na camada gel do muco, e direção do movimento ciliar para região de orofaringe

Fonte: Nakagawa et al.,1997.

O ciclo de batimento ciliar é dividido em duas fases: batimento efetivo e recuperação. Durante o batimento efetivo, o cílio se estende e penetra parcialmente na epífase gel seguindo rápido e perpendicularmente para a superfície celular. Neste momento, descreve um arco que proporciona o estímulo mecânico para a movimentação da camada de muco sentido à 
orofaringe. Na recuperação, o cílio dobra-se lateralmente voltando a sua posição original pela fase. Na fase de recuperação, sua velocidade é duas vezes menor que a do batimento efetivo, além disso, não entra em contato com a epifase gel, diminuindo ao máximo o movimento retrógrado do muco (Sartir e Sleigh, 1990).

O batimento ciliar é influenciado pelas propriedades gerais do muco. Alem disso, contato ideal dos cílios com a superfície sol e gel é fundamental para a eficiência do aparelho mucociliar.

\subsubsection{Transplante Pulmonar e Depuração Mucociliar}

A lesão decorrente da secção e anastomose brônquica tem um papel importante no quadro geral de complicações pós-operatórias. Um grande problema após o TP está relacionado à cicatrização bronquial deficiente, provocando estenose e deiscência (Samano et al., 2009). Além disso, a depuração mucociliar está prejudicada. Sabe-se que esses problemas estão relacionados a uma combinação de múltiplos fatores (Lima et al., 1982; Novick et al., 1991; Veale et al., 1993).

Arumugan et al (1971), observaram o efeito de esteróides e azatioprina sobre a cicatrização da pele abdominal. Eles avaliaram parâmetros como a força tensil de ruptura e o conteúdo de hidroxiprolina nas cicatrizes e observaram que a azatioprina isoladamente ou associada à prednisolona não exerce efeito inibitório na cicatrização. Lima et al (1981), estudaram a cicatrização brônquica e da pele abdominal em cães submetidos 
ao autotransplante com e sem terapia imunossupressora com metiprednisolona e azatioprina durante 23 dias. Observaram que a cicatrização foi prejudicada no grupo submetido à imunossupressão e que a incidência de ruptura e necrose brônquica foi superior nesses animais. Outro estudo avaliou a ação da ciclosporina na cicatrização do brônquio e não encontrou diferença na força tensil de ruptura dos animais tratados em relação aos não tratados (Arumugan e Nimmant, 1971). Auteri et al.(1992), não observaram prejuízo na cicatrização brônquica de animais tratados com prednisona durante 28 dias pós-cirúrgico. Estudos mostram que apenas altas doses de prednisona podem influenciar na cicatrização brônquica (Orens et al., 2006). Esses autores sugerem que a terapia com prednisona não é uma contraindicação ao transplante (Auteri et al., 1992; Orens et al., 2006). McAnally et al (1998), avaliaram os riscos da utilização de prednisona em pacientes transplantados e mostraram que os índices de sobrevida foram muito melhores nos pacientes que receberam doses $<0,42 \mathrm{mg} / \mathrm{kg} / \mathrm{m} 2$ por dia (LD) do que os que receberam doses $>0,42 \mathrm{mg} / \mathrm{kg} / \mathrm{m} 2$ por dia (HD). As mortes no período pós-operatório podem ter sido induzidas pelos esteróides por complicações como baixa cicatrização e infecções.

Os mecanismos envolvidos no prejuízo da depuração mucociliar após o transplante podem estar relacionados a diversos fatores, como o trauma cirúrgico, a desnervação e desvascularização brônquica. (Tomkiewicz et al., 1995; Shankar et al., 1991; Samano et al., 2009).

Com relação à terapia imunossupressora, sabemos que tanto a azatioprina quanto a ciclosporina prejudicam a função mucociliar. 
No entanto, são escassos trabalhos relacionados aos efeitos dos corticosteróides sistêmicos na depuração mucociliar. Investigações in vitro que avaliaram a influência de corticóides tópicos como a budesonida, revelaram diminuição na freqüência do batimento ciliar na mucosa respiratória de animais tratados (Duchateau et al., 1986; Hofmann et al., 1998). Não encontramos trabalhos recentes sobre o tema. 


\section{MÉTODOS}


O presente estudo teve aprovação da Comissão de Ética para Análise de Projetos de Pesquisa (CAPPesq) da Diretoria Clínica do Hospital das Clínicas e da Faculdade de Medicina da Universidade de São Paulo.

Os animais utilizados nos experimentos foram fornecidos pelo biotério central da Faculdade de Medicina da Universidade de São Paulo (FMUSP). Todo o protocolo prático foi desenvolvido no Laboratório de Pesquisa em Cirurgia Torácica da FMUSP - LIM 61.

Foi realizado um estudo experimental, controlado, randomizado e cego, onde foram comparados grupos expostos a três diferentes doses de prednisona, com ou sem cirurgia de secção e anastomose brônquica. O epitélio respiratório foi avaliado através das seguintes variáveis: freqüência de batimento ciliar, transportabilidade do muco e velocidade de transporte mucociliar.

\subsection{Grupos Experimentais}

Foram utilizados 180 ratos machos, Wistar, com peso médio de $300 \mathrm{~g}$. Os animais receberam água e ração balanceada ad libitum. O protocolo foi baseado nos princípios éticos da experimentação animal segundo as normas internacionais vigentes que regem sua utilização na pesquisa científica. 
Os animais foram distribuídos aleatoriamente em seis grupos experimentais:

- Grupo Sal (Grupo Salina; n=30)

Os animais receberam diariamente, por gavagem, volume correspondente a 2,5 ml/kg/dia de Solução de Cloreto de Sódio a 0,9\% durante 30 dias. O grupo foi dividido em três subgrupos $(n=10)$, de acordo com o período de terapia (7, 15 e 30 dias), após o qual os animais foram sacrificados.

- Grupo P1 (Grupo Prednisona 0,625mg/kg; n=30)

Os animais receberam prednisona (Meticorten®, Indústria Química e Farmacêutica Schering-Plough S/A - Rio de Janeiro - RJ) diariamente, por gavagem, na dose de 0,625 mg/kg/dia. O grupo foi dividido em três subgrupos $(n=10)$, de acordo com o período de terapia (7, 15 e 30 dias), após o qual os animais foram sacrificados.

- Grupo P2 (Grupo Prednisona 1,25mg/kg; n=30)

Os animais receberam prednisona diariamente, por gavagem, na dose de 1,25 mg/kg/dia. O grupo foi dividido em três subgrupos $(n=10)$, de acordo com o período de terapia $(7,15$ e 30 dias), após o qual os animais foram sacrificados.

- Grupo P3 (Grupo Prednisona 2,5mg/kg; n=30)

Os animais receberam prednisona diariamente, por gavagem, na dose de 2,5 mg/kg/dia. O grupo foi dividido em três subgrupos $(n=10)$, de acordo com o período de terapia (7, 15 e 30 dias), após o qual os animais foram sacrificados. 
- Grupo SalSc (Grupo Secção Brônquica + Solução Fisiológica; n=30) Após a cirurgia de secção e anastomose brônquica, os animais receberam volume correspondente a $2,5 \mathrm{ml} / \mathrm{kg} / \mathrm{dia}$ de Solução de Cloreto de Sódio a 0,9\% durante 30 dias. O grupo foi dividido em três subgrupos $(n=10)$, de acordo com o período de terapia $(7,15$ e 30 dias), após o qual os animais foram sacrificados.

- Grupo P2Sc (Grupo Secção Brônquica + Prednisona 1,25mg/kg; $\mathrm{n}=30)$

Após a cirurgia de secção e anastomose brônquica, os animais receberam prednisona diariamente, por gavagem, na dose de $1,25 \mathrm{mg} / \mathrm{kg} / \mathrm{dia}$. O grupo foi dividido em três subgrupos $(\mathrm{n}=10)$, de acordo com o período de terapia (7, 15 e 30 dias), após o qual os animais foram sacrificados.

\subsubsection{Formação das chaves de comparação intergrupos}

Para alcançar os dois objetivos propostos neste trabalho formamos duas chaves para comparação dos grupos experimentais descritos acima. Com intuito de responder sobre os efeitos apenas da droga sobre a depuração mucociliar, realizamos a análise estatística comparativa entre os grupos P1, P2, P3 e Sal. Para avaliar a possível interação da droga com o procedimento cirúrgico comparamos os grupos ScP2, ScSal e P2. 


\subsection{Gavagem}

Os animais foram sedados em câmara contendo anestésico inalatório isoflurano (Isothane, Baxter). A solução para administração foi preparada pela dissolução e homogeneização de um comprimido de Prednisona de $5 \mathrm{mg}$ em $10 \mathrm{ml}$ de Solução de Cloreto de Sódio a 0,9\%, o que resultou em uma dose-volume de 1,25 ml/kg/dia para o grupo $\mathrm{P} 1,2,5 \mathrm{ml} / \mathrm{kg} / \mathrm{dia}$ para os grupos P2 e ScP e $5 \mathrm{ml} / \mathrm{kg} /$ dia para o grupo P3. Os animais do grupo Sal receberam diariamente o volume correspondente a $2,5 \mathrm{ml} / \mathrm{kg} / \mathrm{dia}$ de Solução de Cloreto de Sódio a 0,9\%. A gavagem foi realizada por via orogástrica através de cateter de polietileno, número 7 .

\subsection{Secção e Anastomose Brônquica}

Os animais foram sedados em câmara contendo anestésico inalatório isoflurano (Isothane, Baxter), e intubados com cateter de polietileno 14-G de $7,0 \mathrm{~cm}$ de comprimento. A intubação orotraqueal foi realizada com auxílio de laringoscópio pediátrico com lâmina adaptada para o uso em pequenos animais. O cateter foi conectado a um ventilador mecânico (Harvard Apparatus, modelo 683), com volume corrente de $10 \mathrm{ml} / \mathrm{kg}$ de peso corporal e freqüência de 70 ciclos por minuto.

Com o animal posicionado em decúbito lateral direito, realizou-se a assepsia e a tricotomia da região torácica esquerda e a abertura da caixa torácica através de toracotomia esquerda de aproximadamente $3,0 \mathrm{~cm}$ no 
quinto espaço intercostal. Para o procedimento de seç̧ão e anastomose brônquica utilizamos um microscópio estereoscópico trinocular com aumento de 6X (Olympus - SZ61).

O brônquio esquerdo foi isolado da artéria e veia pulmonares através de dissecação e ligado na extremidade proximal, junto à carina, utilizando-se fio de algodão 2-0.
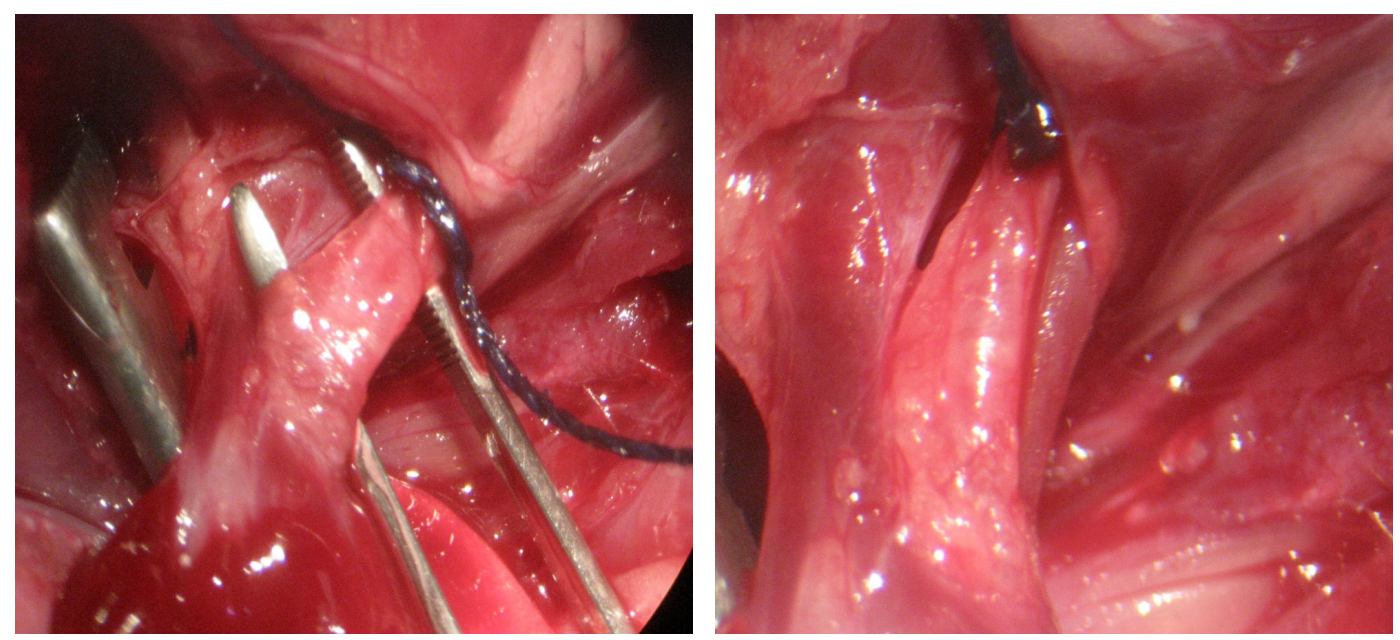

Figura 5. Dissecação do brônquio e ligadura com fio de algodão

Em seguida, o brônquio foi seccionado no seu diâmetro total, próximo à ligadura, e a anastomose brônquica realizada com suturas contínuas, usando fio de polipropileno 8-0, tanto na porção cartilaginosa quanto na membranosa.

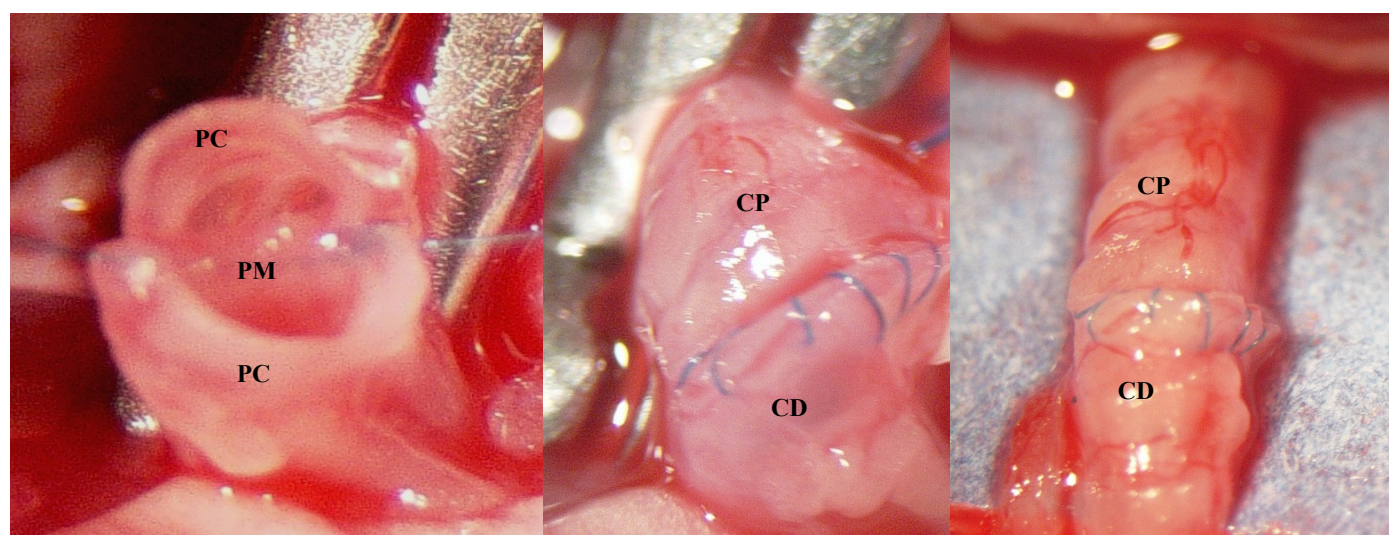

Figura 6. Anastomose do Brônquio esquerdo. Aumento de $8 \mathrm{X}$. PM = porção membranosa $\mathrm{CP}=$ coto proximal $; \mathrm{CD}=$ coto distal 
Finalizada a anastomose, a ligadura brônquica foi retirada, restabelecendo o suprimento de ar para o pulmão esquerdo e a ferida cirúrgica foi submetida à síntese em três planos: intercostal, muscular e cutâneo. O tórax foi drenado por meio de um cateter 19-G, mantido até a retirada total das secreções resultantes do ato cirúrgico.

O aporte anestésico foi interrompido e o animal mantido sob ventilação mecânica, com administração de oxigênio puro, até apresentar sinais de movimento respiratório espontâneo, sendo então, retirado o tubo traqueal.

\subsection{Sacrifício}

Os animais foram anestesiados com tiopental sódico (THIOPENTAX, 0,5g, CRISTÁLIA®) e sacrificados pelo método de exangüinação, através da secção da aorta abdominal.

\subsection{Transportabilidade do muco in vitro}

\subsubsection{Coleta}

Após o sacrifício, os pulmões foram retirados com subseqüente dissecação das vias aéreas superiores. As amostras de muco foram coletadas com auxílio de um pincel de pêlos macios (Tigre ${ }^{\circledR}$, no 02) (Figura 7). 


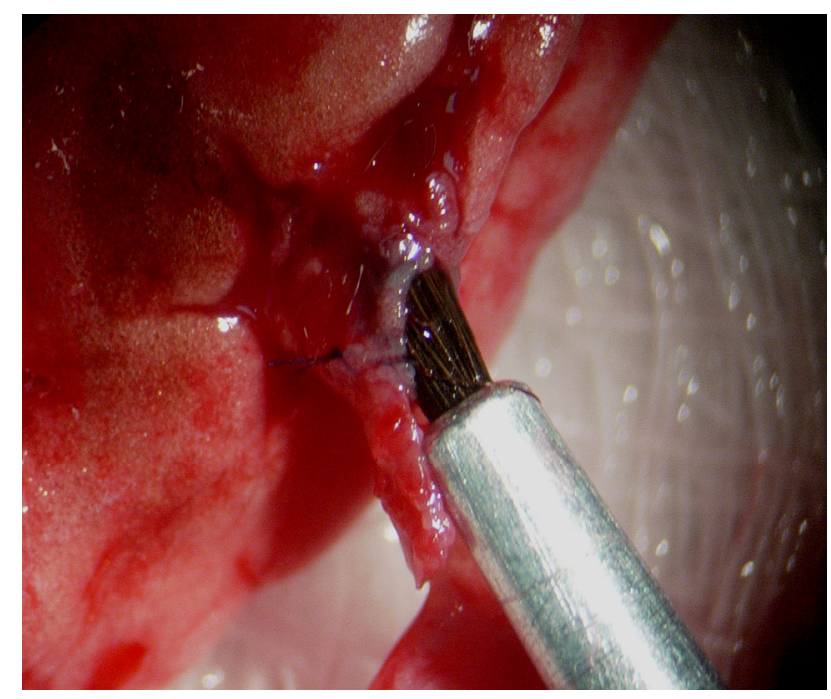

Figura 7. Coleta de amostra de muco do brônquio

O pincel foi posicionado nos brônquios principais através de uma pequena abertura feita na porção cartilaginosa do mesmo. $\mathrm{O}$ muco aderido ao pincel foi colocado sobre uma lâmina histológica contendo óleo mineral e em seguida transferido para um tubo tipo eppendorf. As amostras foram mantidas sob refrigeração a $-70^{\circ} \mathrm{C}$ até a data da análise.

\subsubsection{Análise}

As amostras de muco foram submetidas a um teste classicamente aceito e relatado como sendo um método in vitro: a transportabilidade em palato de rã (Rubin et al., 1990).

A rã (Rana catesbeiana) foi anestesiada através de hipotermia induzida em câmara contendo gelo triturado. Após 50 minutos foram realizados testes para verificação de reflexo. Caso o animal não 
respondesse, ele era decapitado com auxílio de uma guilhotina própria para sacrifício de animais de experimentação. Em seguida o palato foi retirado através de dissecação, tomando-se o devido cuidado para não danificar a superfície epitelial.

O palato permaneceu por 48 horas sob refrigeração a $4^{\circ} \mathrm{C}$ para que $\mathrm{O}$ muco da rã se esgotasse pela ação de seu próprio aparelho ciliar. Uma pequena quantidade de muco foi coletada e armazenada para servir como controle, em relação ao muco dos ratos.

Durante os procedimentos de medida da velocidade, o palato foi mantido sob temperatura ambiente, dentro de uma câmara de acrílico com $100 \%$ de umidade relativa do ar. Tal umidade foi garantida pela vaporização uma solução de Ringer em água destilada (1:1) (73,8 mEq/l Na+, 2mEq// K+, 2,3 mEq// Ca+2 e 78 mEq// Cl-) com auxílio de um nebulizador ultrassônico (mod. US-800, ICEL®).

Para iniciar as medidas, uma pequena alíquota (cerca de $5 \mu l$ ) da amostra de muco estocada em óleo mineral era isolada e mergulhada rapidamente num recipiente contendo éter de petróleo com o objetivo de remover o óleo ao muco aderido. A alíquota de muco foi colocada sobre o epitélio ciliado da região anterior do palato da rã e, durante o seu deslocamento em direção à região posterior, foi cronometrado o tempo gasto para o muco percorrer a distância de $6 \mathrm{~mm}$.

A medida foi feita através da observação do conjunto por meio de um estereomicroscópio (Zeiss), posicionado sobre a tampa da câmara de 
acrílico, composto por uma ocular reticulada. O aumento utilizado foi de $8 x$ (Figuras 8 e 9).

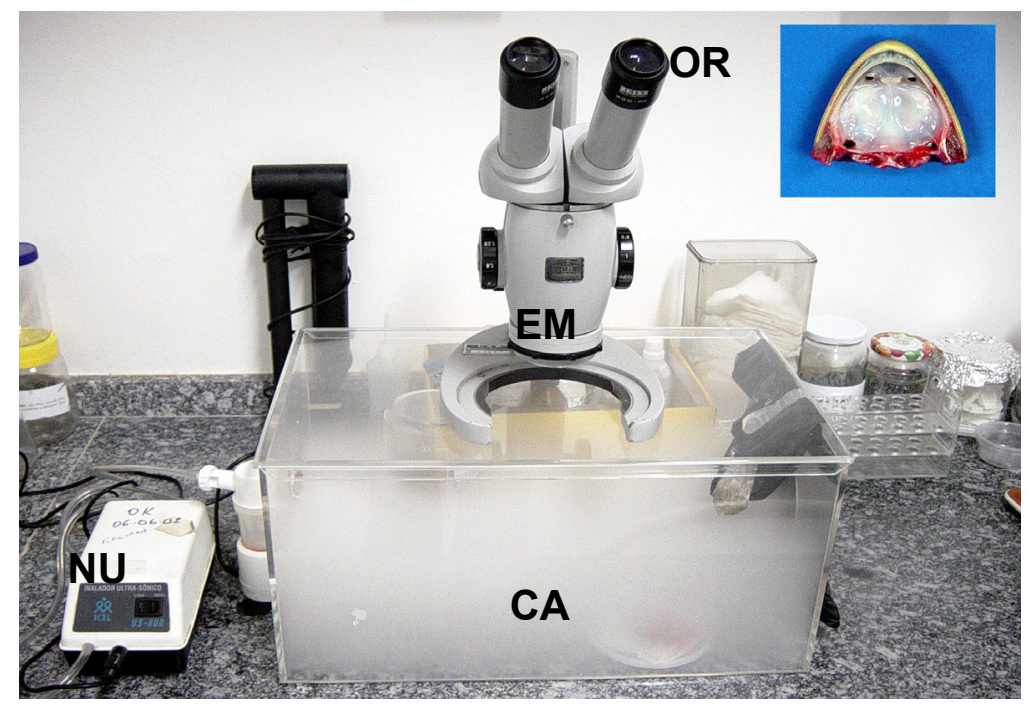

Figura 8. Equipamentos utilizados para medida da transportabilidade das amostras de muco em palato de rã. $\mathrm{NU}$ = nebulizador ultrassônico; $\mathrm{CA}$ = câmara acrílica; $\mathrm{EM}$ = estereomicroscópio; $\mathrm{OR}=$ ocular reticulada

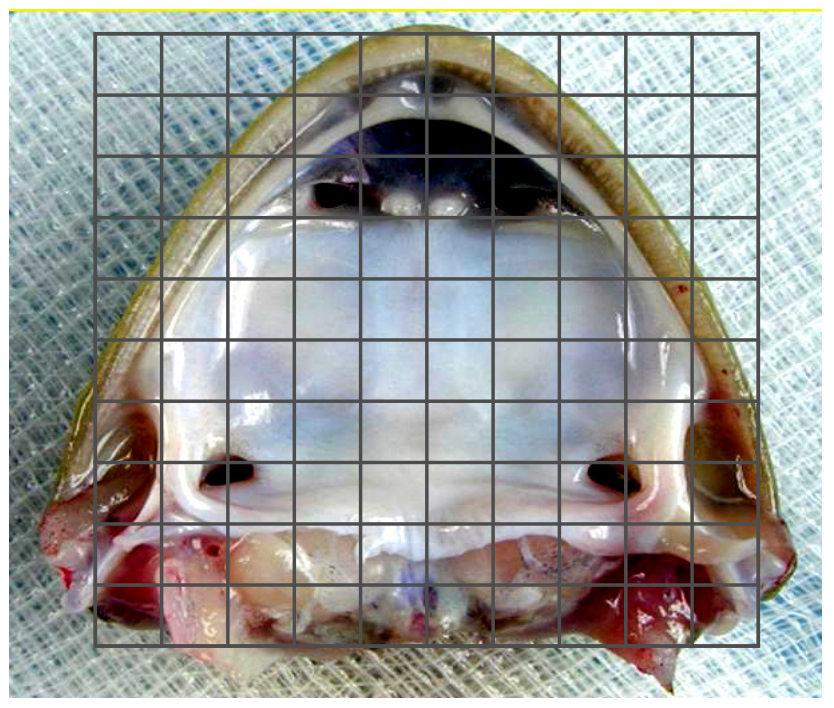

Figura 9. Representação do palato de rã sendo visualizada através de ocular reticulada 
Foram realizadas cinco tomadas de tempo de cada amostra de muco, sendo utilizada, para fins estatísticos, a média aritmética dos valores observados. A cada cinco amostras de muco dos ratos, foi feita a medida da transportabilidade do muco da própria rã.

A velocidade do deslocamento (transportabilidade) das amostras de muco dos ratos (a) foi comparada com a do muco da própria rã (b), sendo, assim, expressa como velocidade relativa (c). Assim, temos: $c=b / a$.

\subsection{Freqüência de Batimento Ciliar in situ}

Realizamos a abertura total das vias aéreas superiores, através de um corte longitudinal no ângulo de contato entre as porções cartilaginosa e membranosa, para exposição do epitélio ciliado.

A imagem do epitélio ciliado brônquico foi captada por uma câmera filmadora (Sony, mod. 3CCD Iris) acoplada a um microscópio óptico (Olympus BX50), com aumento de 100x, e enviada para um monitor de vídeo (Sony Trinitron).

Um estroboscópio (Machine Vision Strobe, mod.5000, U.S.A.), adaptado com fibra óptica, colocado em frente ao epitélio ciliado, emitiu "flashes" a uma freqüência constante conhecida (Figura 6) 


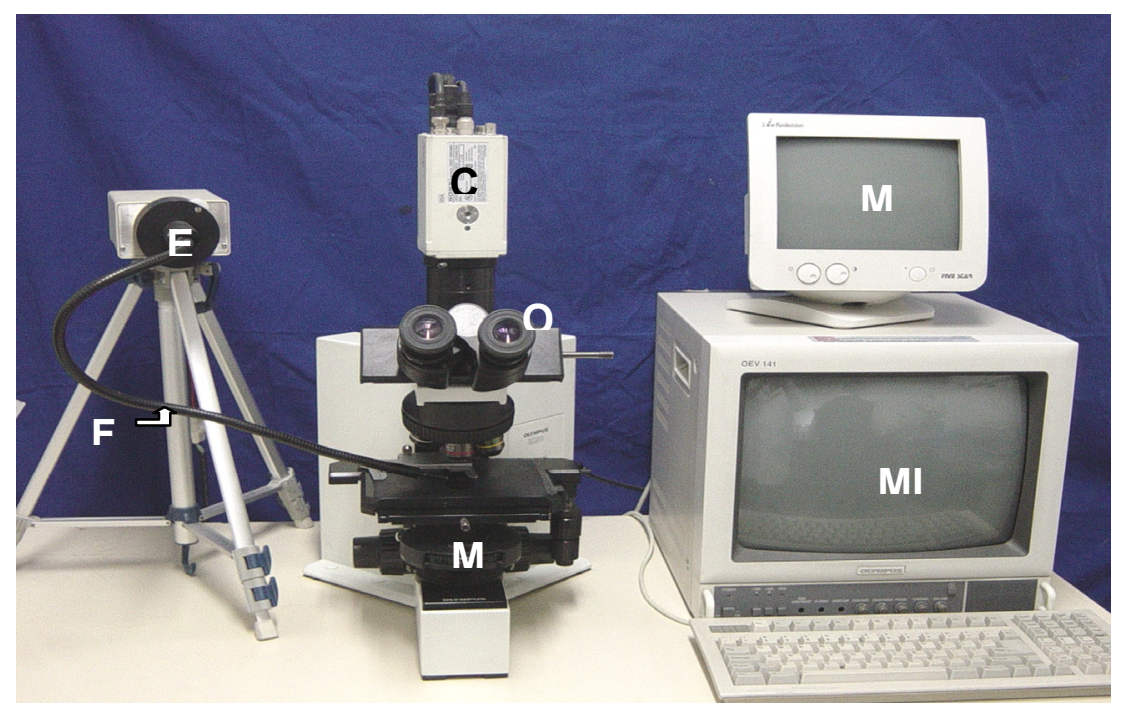

Figura 10. Equipamentos utilizados para medida da freqüência de batimento ciliar e da velocidade de transporte mucociliar. $\mathrm{CF}=$ câmera filmadora; $\mathrm{ES}=$ estroboscópio; $F O=$ fibra óptica; $\mathrm{MF}=$ monitor de freqüência; $\mathrm{MI}=$ monitor de imagem; $\mathrm{MO}=$ microscópio óptico; OR = ocular reticulada

Ao mesmo tempo em que se observa a imagem do epitélio ciliado gerada no monitor, diminui-se a freqüência da luz emitida pelo estroboscópio, até o momento em que não é mais possível a percepção dos movimentos ciliares. Neste ponto, o mesmo valor da freqüência do estroboscópio, registrado no monitor, é atribuído ao batimento ciliar.

\subsection{Velocidade de Transporte Mucociliar in situ}

A Velocidade de Transporte Mucociliar in situ foi medida através da observação direta de partículas aderidas ao muco do epitélio ciliado brônquico.

A observação foi feita com o auxílio de um microscópio óptico (Olympus BX50), equipado com ocular reticulada, sob aumento de 100x. 
A velocidade de deslocamento das partículas aderidas ao muco, ao longo do epitélio ciliado brônquico, foi cronometrada e registrada como a distância que a partícula percorreu num determinado intervalo de tempo ( $\mathrm{mm} / \mathrm{min})$.

\subsection{Análise estatística}

Utilizamos a análise de variância de duplo fator (Droga e tempo) e de triplo fator (Droga, tempo e cirurgia) para verificar a interferência dos fatores analisados sobre a variáveis dependentes, bem como uma possível interação entre eles, seguido do teste post hoc de Bonferroni para as comparações múltiplas entre os grupos. A normalidade e a homogeneidade de variâncias foram avaliadas nos grupos, respectivamente com o teste de Kolmogorov-Smirnov com correção de Lilliefors $(p>0,05$ para todos os grupos) e com o teste de Levene ( $p>0,05)$. As análises estatísticas descritivas e inferenciais foram executadas com o software SPSS versão 13 (SPSS 13.0 for Windows). 
5 RESULTADOS 
A apresentação dos resultados está dividida em duas etapas:

I. Efeitos da terapia com prednisona na depuração mucociliar:

Para avaliar os efeitos das diferentes doses de prednisona na depuração mucociliar comparamos os resultados dos grupos $\mathrm{P} 1$, P2, P3 e Sal. Os resultados estão representados em gráficos de média e desvio padrão.

II. Efeitos da seç̧ão e anastomose brônquica associada à terapia com prednisona:

Para avaliar os efeitos da interação entre a lesão por secção e anastomose brônquica e a terapia com prednisona na depuração mucociliar comparamos os resultados dos grupos SalSc, P2Sc, P2 e Sal. Os resultados estão representados em gráficos de média e desvio padrão.

\section{Etapa I:}

A análise das medidas de Freqüência de Batimento Ciliar (FBC) mostrou pouca variação entre os grupos tanto para a dose quanto para o período de tratamento, não havendo diferença estatística significativa entre estes ( $p=0,089$ e $p=0,175$ respectivamente). 
Tabela 3. Média e desvio-padrão da $F B C(\mathrm{~Hz})$ dos grupos submetidos ou não à terapia com Prednisona

\begin{tabular}{ccccc}
\hline & \multicolumn{4}{c}{ Tempo } \\
\cline { 2 - 4 } Droga & $\mathbf{7}$ dias & 15 dias & 30 dias & Geral Grupos \\
\cline { 2 - 4 } P1 & $9,39+1,06$ & $10,00+0,66$ & $9,76+1,35$ & $9,71+1,04$ \\
P2 & $8,38+1,08$ & $9,49+1,01$ & $9,72+0,96$ & $9,18+1,15$ \\
P3 & $9,38+1,04$ & $8,71+1,34$ & $9,38+0,95$ & $9,16+1,13$ \\
Sal & $9,57+0,54$ & $9,65+0,65$ & $9,56+1,14$ & $9,59+0,81$ \\
\hline Geral Tempos & $9,17+1,04$ & $9,46+1,05$ & $9,60+1,07$ & \\
\hline
\end{tabular}

Tabela 4. Média e desvio-padrão da VTMC ( $\mathrm{mm} / \mathrm{min})$ dos grupos submetidos ou não à terapia com Prednisona

\begin{tabular}{ccccc}
\hline & \multicolumn{3}{c}{ Tempo } & \\
\cline { 2 - 4 } Droga & $\mathbf{7}$ dias & 15 dias & 30 dias & Geral Grupos \\
\hline P1 & $0,57+0,13$ & $0,64+0,18$ & $0,58+0,10$ & $0,60+0,14$ \\
P2 & $0,53+0,08$ & $0,67+0,11$ & $0,57+0,15$ & $0,59+0,13$ \\
P3 & $0,48+0,29$ & $0,54+0,10$ & $0,53+0,16$ & $0,51+0,19$ \\
Sal & $0,62+0,07$ & $0,61+0,07$ & $0,61+0,10$ & $0,61+0,08$ \\
\hline Geral Tempos & $0,55+0,17$ & $0,61+0,13$ & $0,57+0,13$ &
\end{tabular}

Com relação a VTMC, observamos que o grupo P3 difere significativamente do grupo P1 $(p=0,048)$ e do grupo Sal $(p=0,007)$. 
No entanto, o grupo P3 não apresentou diferença $(p=0,066)$ quando comparado ao grupo P2 (Gráfico 1). As demais comparações entre grupos não apresentaram diferença significativa $(p=1,00)$. Os dados também mostram que não houve diferença em relação aos tempos analisados 7, 15 e 30 dias $(p=0,095)$.

Gráfico 1. Velocidade de Transporte Mucociliar dos animais tratados com diferentes doses de prednisona P1, P2, P3 ou com solução fisiológica $0,9 \%$. O grupo P3 apresentou diferença estatística quando comparados aos grupos P1 $\left(p=0,048^{*}\right)$ e Sal $(p=0,007 \#)$

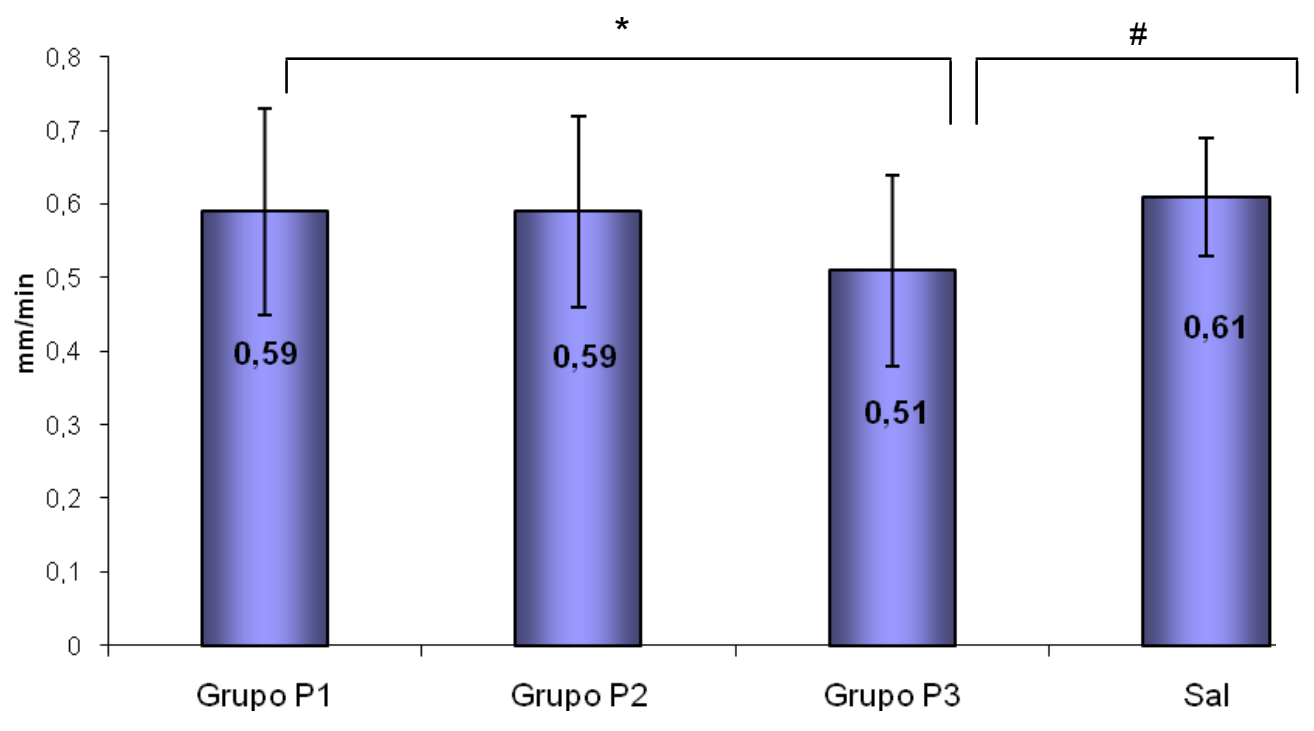

Os grupos submetidos à terapia com prednisona, independente da dose utilizada apresentaram prejuízo na transportabilidade mucociliar quando comparados ao grupo Sal (Gráfico 2). O grupo salina diferiu 
significativamente do grupo P1 $(p=0,02)$, P1 $(p=0,02)$ e P3 $(p=0,03)$. O tempo de terapia não influenciou a TM $(p=0,719)$.

Gráfico 2. Transportabilidade do muco dos animais tratados com diferentes doses de prednisona P1, P2, P3 ou com solução fisiológica 0,9\% Grupo Sal. Os animais tratados com prednisona mostraram redução significativa de TM ( ${ }^{*} p<0,03$ vs Grupo Sal)

Influência da Prednisona

Transportabilidade do muco "in vitro"

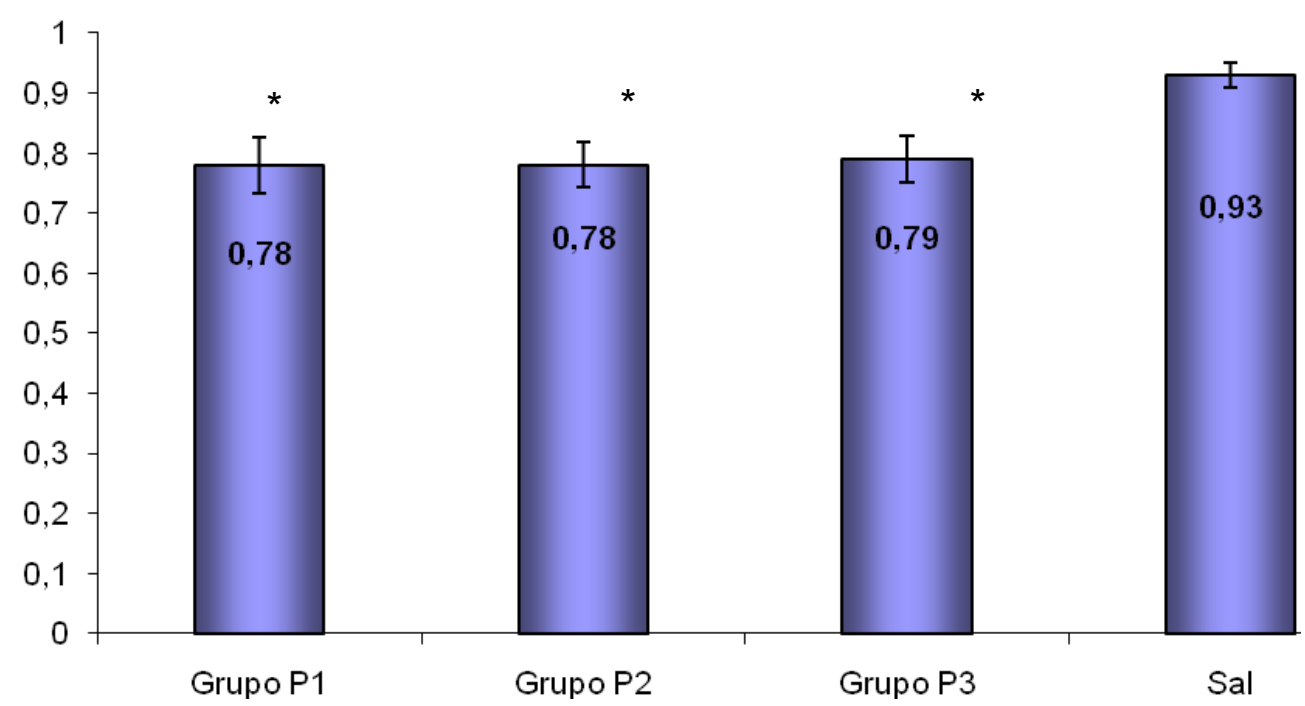

Não houve interação entre a terapia utilizada e o período de tratamento para as três variáveis utilizadas: FBC, VTMC e TM $(p=0,10$; $p=0,71$ e $p=0,64$ respectivamente). 


\section{Etapa II:}

Os animais submetidos à secção e anastomose brônquica tiveram redução significativa da $\mathrm{FBC}$ após 7 e 15 dias do procedimento cirúrgico $(p<0,001)$. Observamos a recuperação deste parâmetro após 30 dias (Gráfico 3).

Gráfico 3. Freqüência de batimento dos grupos submetidos à cirurgia de secção e anastomose brônquica e dos não submetidos à cirurgia. Os animais do grupo SalSc mostraram redução significativa de FBC nos grupos avaliados após 7 e 15 dias ( $\left.{ }^{*} p<0,001\right)$ quando comparados com o grupo Sal. Os animais submetidos a cirurgia de secção e anastomose brônquica apresentaram diferença entre si ( \# vs SalSc 30 dias). Os grupos avaliados após 30 dias não apresentaram diferença estatística entre si

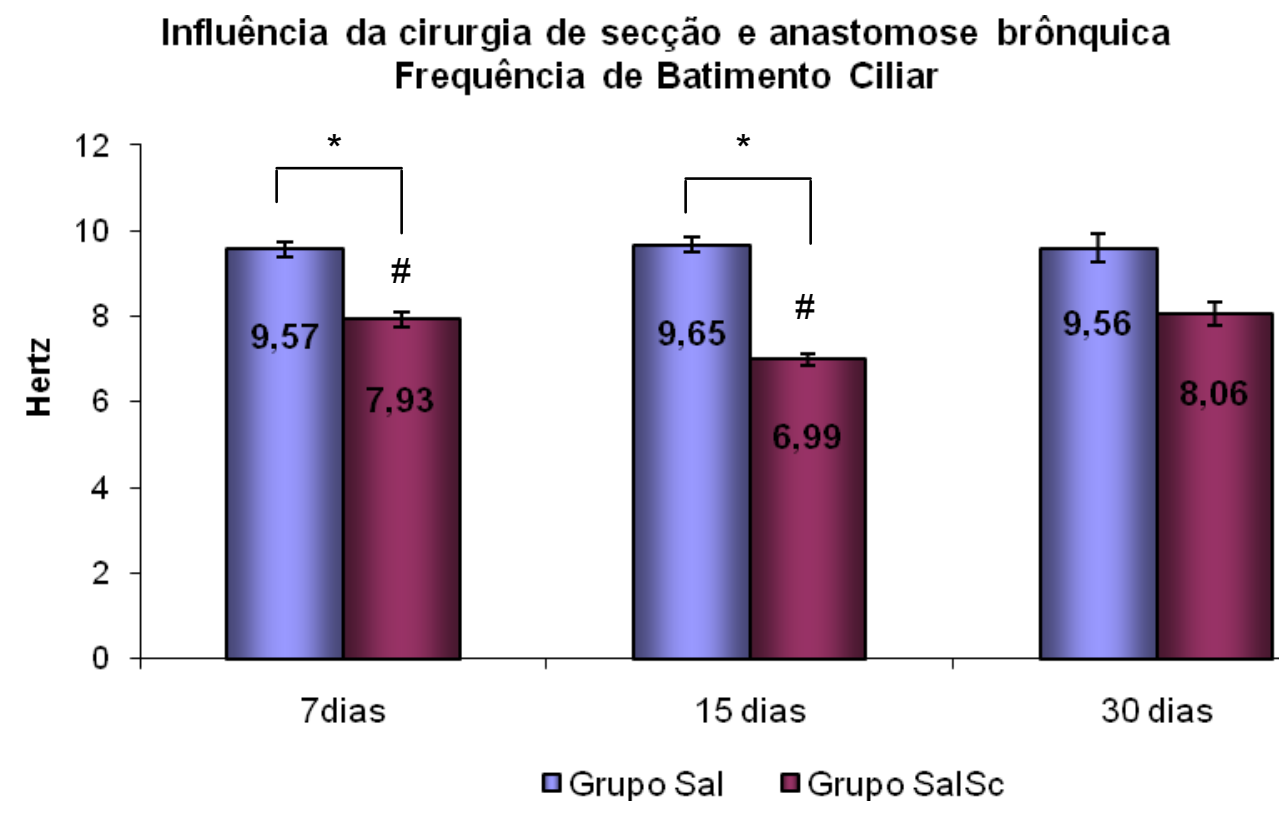


Os grupos SalSc e P2Sc não apresentaram diferença estatística entre si quanto à $\operatorname{FBC}(p=0,84)$, mas tiveram prejuízo nessa variável em relação ao grupo P2 ( $p<0,001)$, como podemos observar no gráfico 4 .

Gráfico 4. Freqüência de batimento ciliar dos grupos submetidos à cirurgia de secção e anastomose brônquica e ao tratamento com prednisona. Houve diferença estatisticamente significativa entre os grupos ( ${ }^{*}$ vs Grupo P2, $p<0,001$ )

\section{Influência da Cirurgia e Prednisona \\ Frequência de Batimento Ciliar}

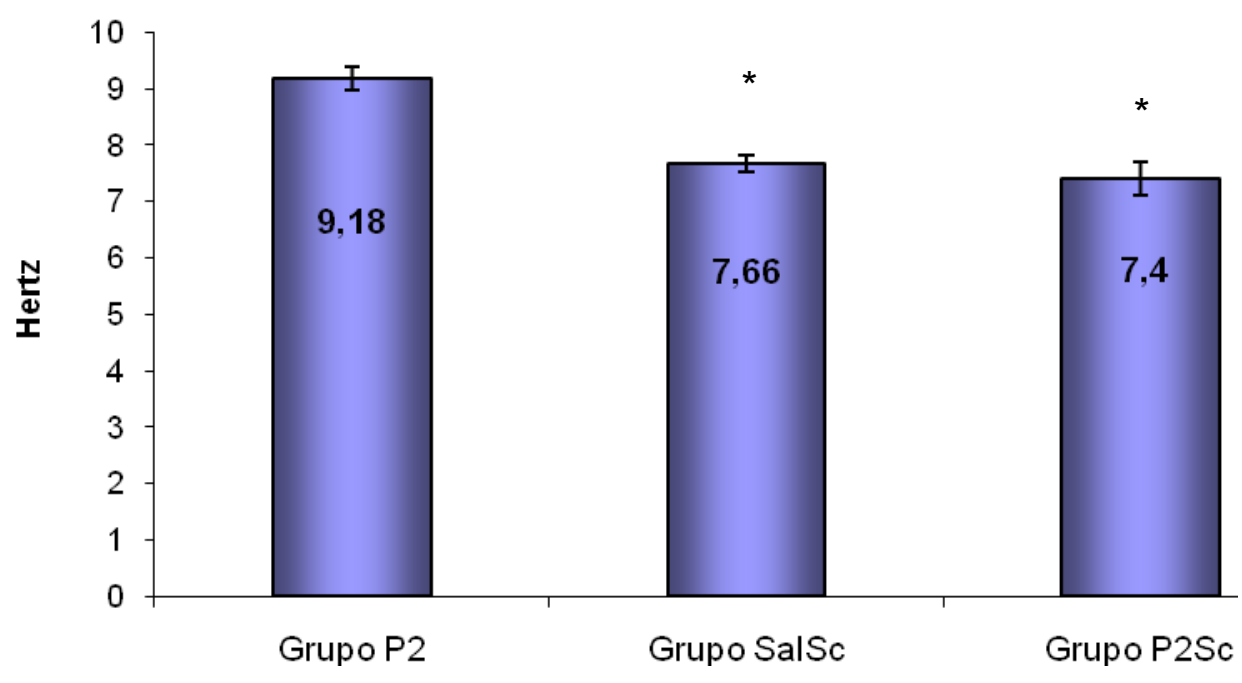


Tabela 5. Média e desvio-padrão do FBC (Hertz) dos grupos submetidos ou não à cirurgia de secção e anastomose brônquica

\begin{tabular}{|c|c|c|c|c|c|}
\hline Cirurgia & Tempo & Média & $d p$ & Mínimo & Máximo \\
\hline & 7 dias & 6,57 & 1,44 & 5,21 & 9,30 \\
\hline \multirow[t]{3}{*}{ P2Sc } & 15 dias & 6,65 & 1,30 & 5,30 & 9,14 \\
\hline & 30 dias & 8,77 & 0,84 & 7,11 & 10,06 \\
\hline & 7 dias & 8,38 & 1,08 & 6,54 & 9,68 \\
\hline \multirow[t]{3}{*}{ P2 } & 15 dias & 9,49 & 1,01 & 8,14 & 11,00 \\
\hline & 30 dias & 9,72 & 0,96 & 7,51 & 10,80 \\
\hline & 7 dias & 7,93 & 0,57 & 7,12 & 8,82 \\
\hline \multirow[t]{3}{*}{ SalSc } & 15 dias & 6,99 & 0,46 & 6,21 & 7,50 \\
\hline & 30 dias & 8,07 & 0,91 & 6,55 & 9,41 \\
\hline & 7 dias & 9,57 & 0,54 & 9,02 & 10,56 \\
\hline \multirow[t]{2}{*}{ Sal } & 15 dias & 9,65 & 0,65 & 9,10 & 10,88 \\
\hline & 30 dias & 9,56 & 1,14 & 8,24 & 11,45 \\
\hline
\end{tabular}


$\mathrm{Na}$ avaliação da VTMC, observamos que animais do grupo SalSc mostraram redução significativa nos grupos avaliados após 7 e 15 dias ( $p<0,001)$ quando comparados com o grupo Sal; já os grupos avaliados após 30 dias não apresentaram diferença significativa $(p=0,139)$. Na cirurgia, observamos que os animais avaliados após 7 e 15 dias apresentaram diferença estatística significativa $(p<0,001)$ em relação aos animais avaliados após 30 dias (Gráfico 5 ).

Gráfico 5. Velocidade de Transporte dos grupos submetidos à cirurgia de secção e anastomose brônquica e dos não submetidos à cirurgia. Os animais do grupo SalSc mostraram redução significativa de VTMC nos grupos avaliados após 7 e 15 dias (* $p<0,001)$ quando comparados com o grupo Sal. Os grupos avaliados após 30 dias não apresentaram diferença estatística entre si. Os grupos SalSc -7 e 15 dias apresentaram menor VTMC comparados ao grupo SalSc-30 dias (\# Vs SalSc 30dias, $p<0,001$ )

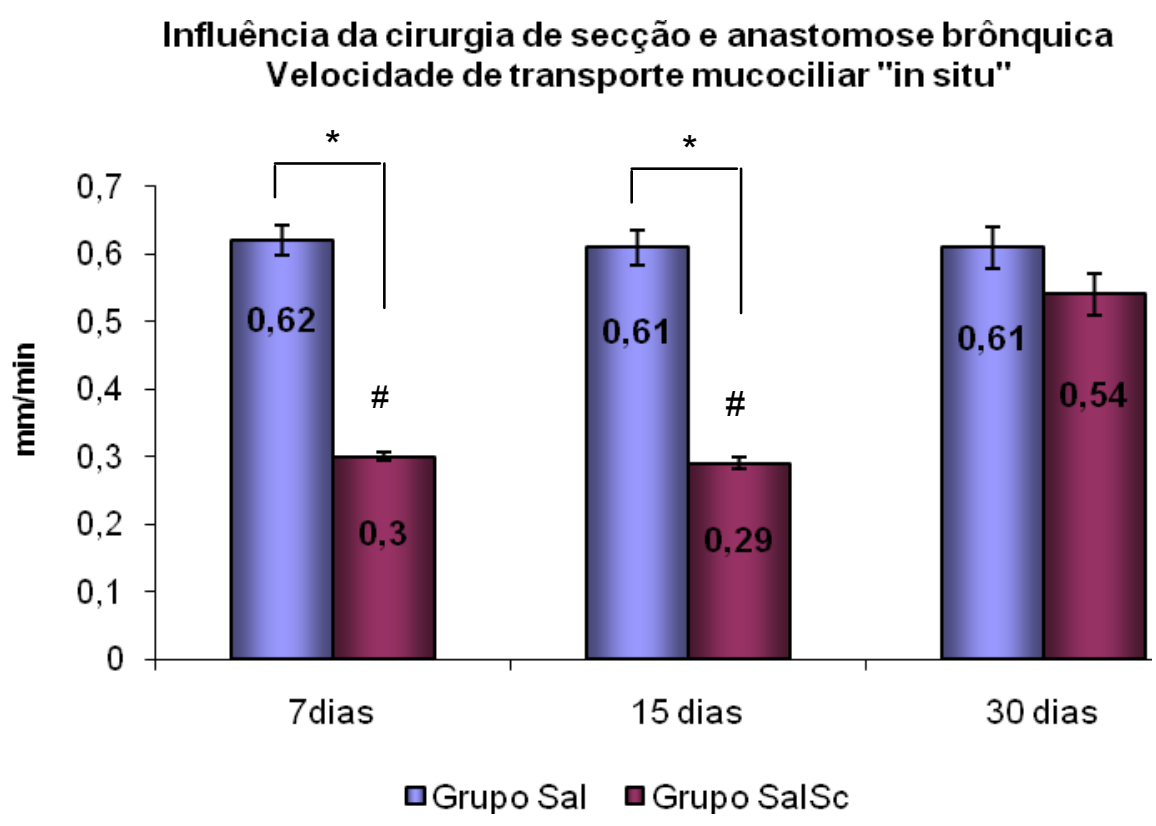


Tabela 6. Média e desvio-padrão do VTMC ( $\mathrm{mm} / \mathrm{min})$ dos grupos submetidos ou não à cirurgia de secção e anastomose brônquica

\begin{tabular}{|c|c|c|c|c|c|}
\hline Grupo & Tempo & Média & $d p$ & Mínimo & Máximo \\
\hline & 7 dias & 0,27 & 0,07 & 0,19 & 0,42 \\
\hline \multirow[t]{3}{*}{ P2Sc } & 15 dias & 0,30 & 0,13 & 0,12 & 0,55 \\
\hline & 30 dias & 0,52 & 0,18 & 0,32 & 0,94 \\
\hline & 7 dias & 0,53 & 0,08 & 0,45 & 0,67 \\
\hline \multirow[t]{3}{*}{ P2 } & 15 dias & 0,67 & 0,11 & 0,52 & 0,90 \\
\hline & 30 dias & 0,57 & 0,15 & 0,25 & 0,75 \\
\hline & 7 dias & 0,30 & 0,02 & 0,28 & 0,33 \\
\hline \multirow[t]{3}{*}{ SalSc } & 15 dias & 0,29 & 0,03 & 0,26 & 0,34 \\
\hline & 30 dias & 0,54 & 0,10 & 0,41 & 0,70 \\
\hline & 7 dias & 0,62 & 0,07 & 0,53 & 0,72 \\
\hline \multirow[t]{2}{*}{ Sal } & 15 dias & 0,61 & 0,07 & 0,49 & 0,70 \\
\hline & 30 dias & 0,61 & 0,10 & 0,44 & 0,83 \\
\hline
\end{tabular}


Nos grupos SalSc e P2Sc a VTMC foi menor após 7 e 15 da cirurgia $(p<0,05)$ comparado aos animais de 30 dias (Gráfico 6).

Gráfico 6. Velocidade de transporte mucociliar dos grupos submetidos à cirurgia de secção e anastomose brônquica e ao tratamento com prednisona. Houve diferença estatisticamente significativa entre os grupos (*vs Grupo P2, $p<0,001$ )

Influência da Cirurgia e Prednisona

Velocidade de Transporte Mucociliar "in situ"

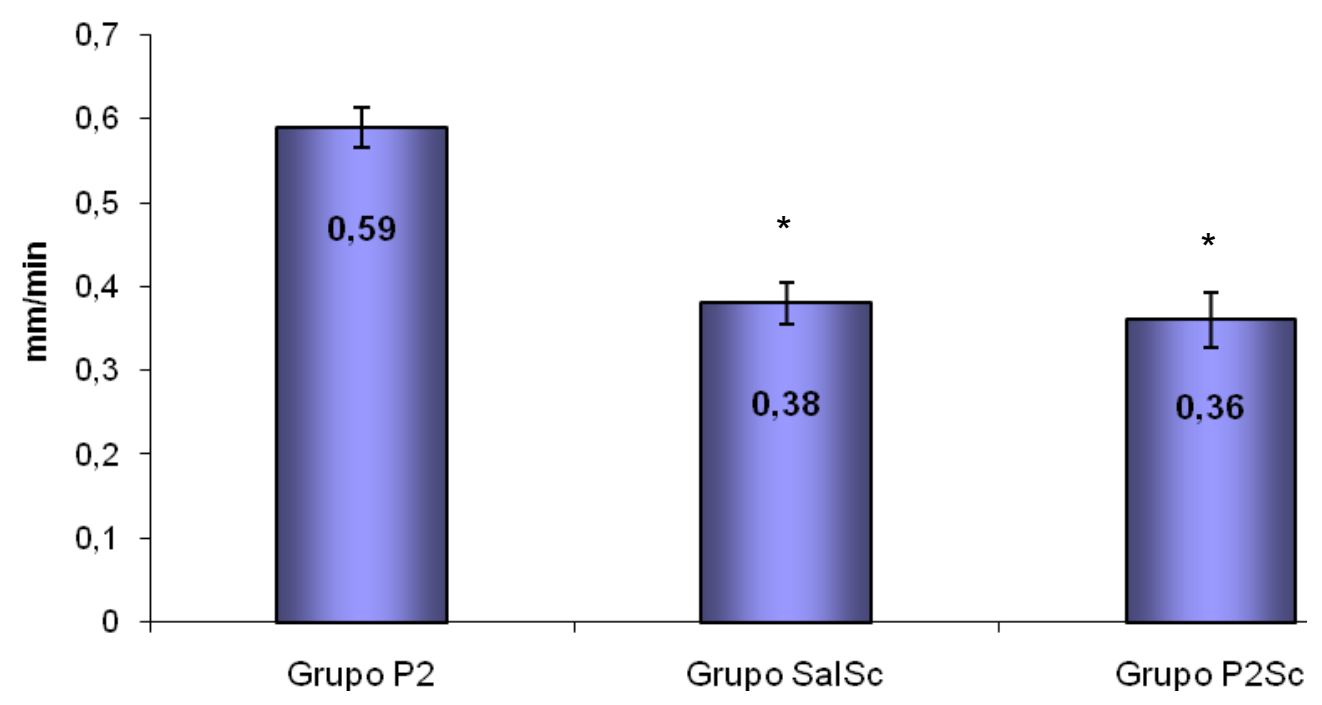


Tabela 7. Média e desvio-padrão da TM dos grupos submetidos ou não à cirurgia de secção e anastomose brônquica

\begin{tabular}{|c|c|c|c|c|c|}
\hline Cirurgia & Tempo & Média & $d p$ & Mínimo & Máximo \\
\hline & 7 dias & 0,64 & 0,12 & 0,44 & 0,84 \\
\hline \multirow[t]{3}{*}{ P2Sc } & 15 dias & 0,80 & 0,17 & 0,56 & 1,08 \\
\hline & 30 dias & 0,65 & 0,15 & 0,47 & 0,84 \\
\hline & 7 dias & 0,83 & 0,15 & 0,59 & 1,03 \\
\hline \multirow[t]{3}{*}{ P2 } & 15 dias & 0,84 & 0,16 & 0,62 & 1,04 \\
\hline & 30 dias & 0,68 & 0,21 & 0,23 & 1,00 \\
\hline & 7 dias & 0,58 & 0,06 & 0,52 & 0,68 \\
\hline \multirow[t]{3}{*}{ SalSc } & 15 dias & 0,58 & 0,06 & 0,52 & 0,68 \\
\hline & 30 dias & 0,54 & 0,06 & 0,45 & 0,68 \\
\hline & 7 dias & 0,94 & 0,03 & 0,91 & 1,01 \\
\hline \multirow[t]{2}{*}{ Sal } & 15 dias & 0,94 & 0,04 & 0,89 & 1,01 \\
\hline & 30 dias & 0,92 & 0,20 & 0,56 & 1,22 \\
\hline
\end{tabular}


A TM foi prejudicada nos grupos submetidos à cirurgia de secção e anastomose brônquica em todos os períodos $(p<0,001)$, como representado no Gráfico 7.

Gráfico 7. Transportabilidade do muco dos grupos submetidos à cirurgia de secção e anastomose brônquica e dos não submetidos à cirurgia. Os animais do grupo SalSc mostraram redução significativa de TM em todos os períodos avaliados (* $p<0,001)$ quando comparados com o grupo Sal

\section{Influência da Cirurgia de secção e anastomose brônquica Tranportabilidade do muco "in vitro"}

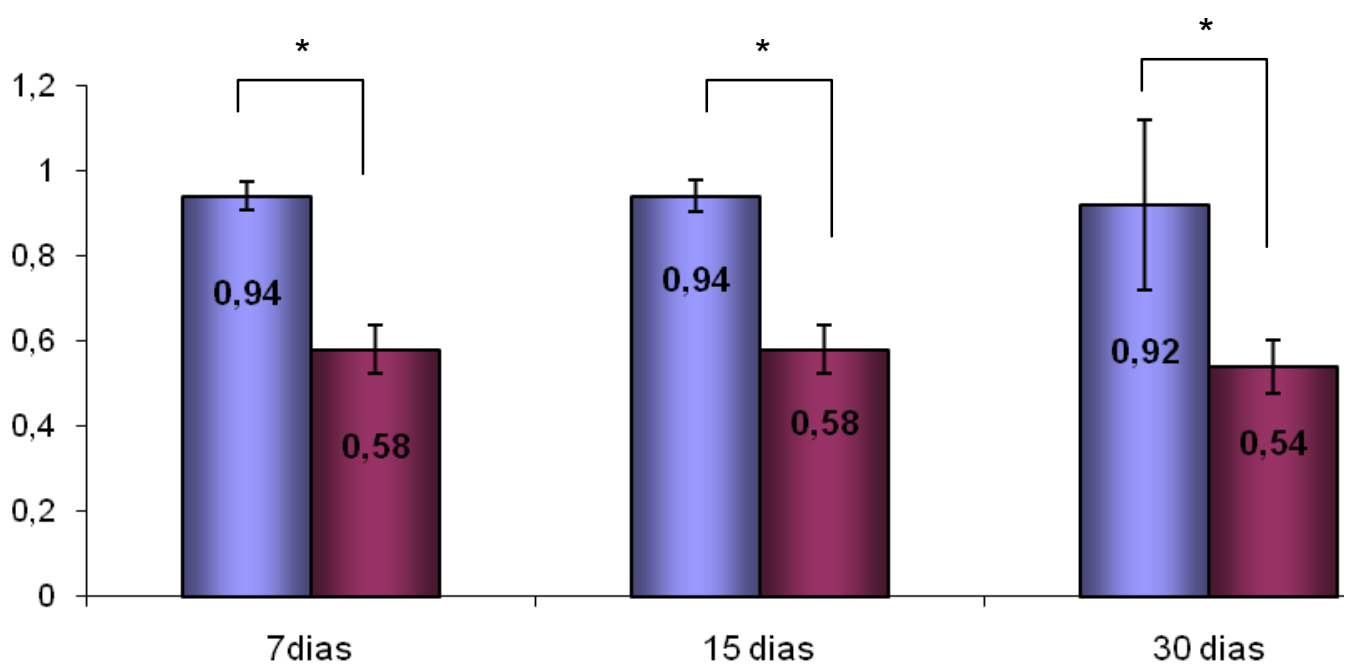

口Grupo Sal $\square$ Grupo SalSc

O grupo P2Sc apresentou menor TM em relação a P2 $(p=0,02)$ e maior TM em relação a SalSc (Gráfico 8). Não houve interação entre a droga, cirurgia e o tempo $(p=0,3346)$. 
Gráfico 8. Transportabilidade do muco "in vitro" dos grupos submetidos à cirurgia de secção e anastomose brônquica e ao tratamento com prednisona. O grupo P2Sc apresentou diferença significativa em relação aos grupos P2 e SalSc $\left({ }^{\#} p<0,001\right.$ e * $P=0,02)$

$$
\begin{aligned}
& \text { Influência da Cirurgia e Prednisona } \\
& \text { Transportabilidade do muco "in vitro" }
\end{aligned}
$$

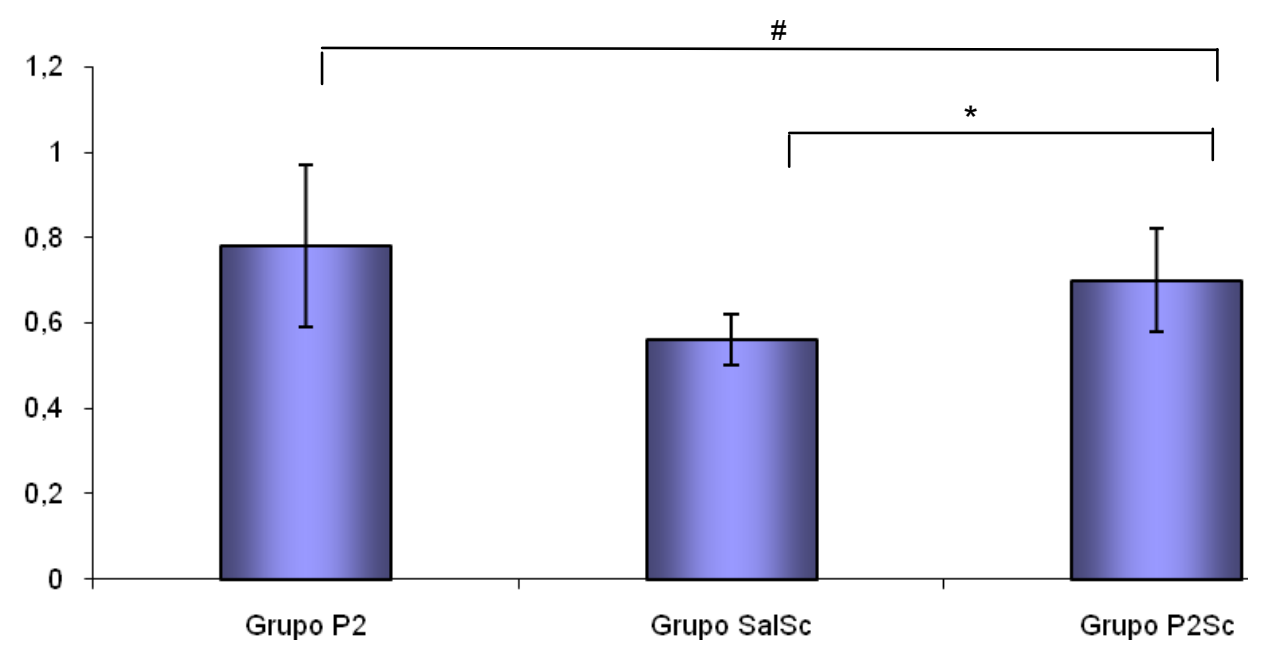


Durante a respiração normal, o ar inalado carrega grande quantidade de microorganismos, material particulado e outros poluentes para os pulmões, sendo que parte destes agentes se deposita nas vias aéreas aderindo ao muco que recobre seu epitélio. A remoção desses agentes ocorre através do TMC para a região de orofaringe onde serão deglutidos ou expectorados. A depuração mucociliar está prejudicada em diversas condições respiratórias como em pacientes com bronquiolite crônica, fibrose cística e asma (Barroso et al., 1992; Alegra et al., 1989, Wagner e Headley, 2003; Bush et al., 2006). Além disso, as drogas administradas nesses casos podem influenciar o transporte mucociliar (Aquino, 2009).

Nosso estudo avaliou a influência da prednisona na depuração mucociliar assim como a ação conjunta desta droga com o procedimento de secção e anastomose brônquica. A prednisona foi escolhida por ser amplamente usada em pacientes receptores de pulmões. A via de administração, freqüentemente utilizada em transplantados é a oral. A dosagem intermediária foi baseada na literatura disponível (McAnally et al., 2006; Silva 2008).

Foram analisadas três variáveis relacionadas à depuração mucociliar capazes de demonstrar características importantes para a efetividade desse sistema: a transportabilidade do muco, a freqüência de batimento ciliar e a velocidade de transporte mucociliar (Macchione et al., 1995; Trindade et al., 2007). 


\section{$\underline{\text { Transportabilidade do muco }}$}

A transportabilidade do muco é uma característica diretamente relacionada à composição química deste. Esta composição garante a ele um componente elástico e deformável, importante para seu deslocamento diante da energia transmitida pelo batimento ciliar. Alterações na composição do muco podem influenciar de maneira importante a transportabilidade, a efetividade do batimento ciliar e conseqüentemente a depuração mucociliar (Albertini-Yagi, 2005).

O epitélio de palato de rã, utilizado como modelo de análise para o presente trabalho, apresenta várias características em comum com o epitélio pseudoestratificado das vias aéreas de mamíferos constituindo um modelo confiável nos estudos de transportabilidade de muco (Saldiva, 1990, Albertini Yagi et al., 2005; Trindade et al.,2007). Os experimentos foram realizados à temperatura de $20^{\circ} \mathrm{C}$ e os palatos mantidos em uma câmara acrílica com $100 \%$ de umidade. Com estas condições controladas, a preparação do palato de rã é considerada ideal tendo como variáveis relevantes apenas as propriedades físicas do muco (Rubin et al., 1990)

As amostras de muco foram estocadas em óleo mineral até o momento da análise quando eram mergulhadas rapidamente num recipiente contendo éter de petróleo. O éter foi utilizado com o objetivo de remover o óleo ao muco aderido. Rubin et al. (1990) demonstraram que este procedimento não altera a transportabilidade e as características químicas do muco.

Observamos que a prednisona interfere na qualidade do muco diminuindo sua transportabilidade. Este resultado foi observado para todas 
as dosagens estudadas sem diferença estatística entre elas. Tal fato demonstra que a prednisona altera as características do muco mesmo quando administrada em baixas dosagens.

Sabemos que a prednisona diminui a expressão de genes relacionados à produção de proteínas presentes no muco (Marom et al., 1984). Estudos experimentais mostraram que a terapia com corticóides, como a betametasona, pode suprimir a produção de muco inibindo diretamente as células caliciformes e também pode reduzir as citocinas pró-inflamatórias que estimulam a produção de muco (Kai et al.,1996; Lu et al., 2005). A alteração na produção de proteínas modifica as características do muco e está diretamente relacionada ao prejuízo de sua transportabilidade.

A concentração de mucinas ou glicoproteínas do muco como a fucose (produzidas pelas glândulas submucosas e células caliciformes) e da lgG, (parte de produção local e outra da porção sérica), parecem ser o principal fator determinante tanto da viscosidade quanto da elasticidade de amostras do muco ( Majima et al., 1999).

Estudos relatam a diminuição na produção de mucinas e melhora na transportabilidade mucociliar de asmáticos após tratamento com corticóides. Tais resultados são justificáveis visto que os modelos animais de inflamação apresentam hipersecreção de muco com diminuição da transportabilidade deste (Schuhl et al., 1990; Fraser et al,1999). Apesar de não se conhecer exatamente os mecanismos, sabe-se que a lgG aumenta a viscoelasticidade do muco. Desta forma, o controle de processos inflamatórios diminui a viscoelasticidade em resposta à queda dos níveis de lgG no muco (Majima 
et al.,1999). Nesses casos, é compreensível a melhora dessa variável na medida em que a prednisona melhora a condição inflamatória geral do paciente. Já o nosso estudo utilizou animais livres de doenças, cuja única condição era a terapia diária com o corticóide; nesse caso o medicamento prejudicou a transportabilidade do muco.

Um dos nossos objetivos, além de verificar a influência da prednisona na transportabilidade do muco, foi o de avaliar a associação dessa droga à lesão cirúrgica pós-secção e anastomose brônquica. Para poder fazer comparações múltiplas envolvendo animais submetidos a essa associação e aos submetidos apenas ao procedimento cirúrgico, inserimos no estudo o grupo ScSal (submetidos à cirurgia de secção e tratado com solução fisiológica). Diversos trabalhos na literatura já avaliaram características da depuração mucociliar em animais submetidos à cirurgia de secção e anastomose brônquica. No entanto, era metodologicamente necessária a inserção deste grupo no nosso desenho de estudo para tornar nossas comparações mais consistentes.

Observamos a diminuição da transportabilidade do muco após a cirurgia de secção e anastomose brônquica nos três períodos estudados 7 , 15 e 30 dias. Em estudo prévio, que avaliou os efeitos da cirurgia de secção e anastomose brônquica unilateral na transportabilidade do muco, não verificou alterações nesse parâmetro (Rivero et al., 2001). No entanto, tal estudo apresentou metodologia diferente da nossa, já que utilizou o brônquio contralateral como controle, ou seja, a cirurgia era feita no brônquio esquerdo e o brônquio direito era utilizado como controle. No presente 
trabalho utilizamos um animal sem intervenção cirúrgica como controle, pois consideramos que apesar da lesão ter sido provocada no brônquio esquerdo, um processo inflamatório difuso pode influenciar a produção e conseqüentemente a transportabilidade do muco contralateral. Acreditamos que a diferença metodológica justifica a diferença nos resultados obtidos.

Verificamos que a terapia com prednisona, após a cirurgia de secção e anastomose brônquica, melhora a transportabilidade do muco quando comparamos esses animais aos do grupo submetido apenas ao procedimento cirúrgico. Tal resultado reforça a idéia de que, em situações onde o processo inflamatório é ativado, a prednisona altera a qualidade do muco melhorando sua transportabilidade. Além disso, a prednisona melhora o circulação brônquica pós transplante. Inui et al. (1993), estudou a circulação brônquica de animais transplantados submetidos a um protocolo imunossupressor (azatioprina e ciclosporina) acrescido ou não de prednisolona e verificou melhora do fluxo sanguíneo e diminuição da isquemia brônquica no grupo que recebeu o corticóide.

Por outro lado, essa variável ainda permaneceu inferior em relação às do grupo submetido à terapia com salina (Sal) ou mesmo com prednisona (P2).

A grande dificuldade no estudo do muco respiratório é a falta de métodos simples e pouco invasivos que proporcionem a obtenção de quantidades suficientes das secreções respiratórias. No início do estudo planejamos a realização de metodologia para caracterização das propriedades reológicas do muco através da medida do ângulo de contato muco/superfície. No entanto, não foi possível sua realização dada a 
pequena quantidade de muco possível de ser coletada de ratos. O laboratório também dispõe de um viscosímetro, mas que no estudo com ratos também tem sua utilização limitada pela pouca quantidade de muco disponível. Tais técnicas poderiam elucidar com mais detalhes as mudanças verificadas na transportabilidade do muco, no entanto, só poderiam ser utilizadas se o modelo animal utilizado fosse maior, o que certamente aumentaria as dificuldades de execução e os recursos necessários para o desenvolvimento do protocolo. Uma possibilidade futura de estudos na área é o emprego dessas técnicas em amostras de muco de pacientes usuários da corticoterapia ou mesmo de transplantados para avaliação do muco por eles produzido e estabelecer assim um paralelo com a depuração mucociliar e os quadros de infecção observados nestes pacientes.

\section{Freqüência de batimento ciliar}

O batimento ciliar deve apresentar uma freqüência adequada e seqüência coordenada, produzindo uma onda, cujo mecanismo de controle permanece desconhecido. Alterações na freqüência de batimento ciliar podem refletir problemas na ultra-estrutura dos cílios, como ausência dos braços internos ou externos de dineína, deleção ou transposição de pares de microtúbulos centrais ou periféricos (Chilvers et al., 2003). Esta freqüência também depende das propriedades viscoelásticas e de transporte do muco respiratório. 
Não observamos diferença entre os grupos tratados com prednisona nos períodos estudados, o que indica que a prednisona não altera a freqüência de batimento ciliar. Não encontramos na literatura trabalhos que avaliem a ação da prednisona de uso sistêmico na freqüência de batimento ciliar.

Investigações in vitro, que avaliaram a influência de corticosteróides tópicos como a budesonida, revelaram diminuição na freqüência do batimento ciliar na mucosa respiratória de animais tratados (Duchateau et al., 1986; Hofmann., 1998). No entanto, tais estudos sugerem que os danos causados ao sistema mucociliar estão mais relacionados às soluções de preservação destes medicamentos, como o cloreto de benzalcônio, do que propriamente aos corticosteróides (Braat et al., 1995; Berg et al.,1997). Klossek et al. (2001) realizaram um estudo prospectivo abordando o efeito do acetonido de triancilonona (corticóide sintético), utilizado por período prolongado, não revelando comprometimento da função ciliar de pacientes com rinite alérgica.

Com relação à cirurgia de secção e anastomose brônquica, observamos redução da freqüência de batimento ciliar nos animais avaliados após 7 e 15 dias do procedimento cirúrgico. Tais complicações decorrem da desnervação autonômica e interrupção do suprimento sanguíneo após a secção e sem o restabelecimento da circulação brônquica após a cirurgia. Vários estudos demonstraram a diminuição da função ciliar ocasionada pela lesão brônquica. Pazetti et al. (2008) verificou prejuízo da freqüência de batimento ciliar dos animais submetidos à cirurgia de secção e anastomose brônquica e avaliados 
após 30 dias do procedimento cirúrgico. O mesmo resultado foi verificado por Veale et al. (1993) ao estudar a região brônquica de anastomose de pacientes submetidos ao transplante de pulmão comparadas aos brônquios contralaterais não transplantado (nativos).

Observamos que os grupos sacrificados após 30 dias apresentaram melhora nos parâmetros avaliados em relação aos grupos sacrificados depois de 7 e 15 dias da cirurgia, sugerindo regeneração do epitélio ciliado brônquico nesses animais bem como da função da célula ciliada. Apesar de o presente estudo ter verificado recuperação desse parâmetro aos 30 dias da cirurgia, a literatura é controversa com relação ao período em que se inicia a verificação do processo regenerativo. Estudo envolvendo transplante pulmonar em cães observou recuperação do transporte mucociliar logo nas primeiras semanas após a cirurgia (Brody et al., 1972). Pazetti et al., 2008 verificou diminuição da freqüência de batimento ciliar após 30 dias com uma tendência de recuperação observada nos animais avaliados tardiamente, no caso após 90 dias do procedimento cirúrgico. Tal controvérsia pode advir de um período de transição desta recuperação que precisa ser melhor investigado.

Provavelmente, os resultados relacionados à diminuição da freqüência de batimento ciliar estão relacionados à desnervação e desvascularização brônquica além da destruição do epitélio local. O procedimento de secção e anastomose brônquica envolvido no transplante, por vezes ocasiona complicações no período pós-operatório como estenose, deiscência, malacia, granuloma e infecção (Samano et al., 2009). Tais complicações 
decorrem da desnervação autonômica e interrupção do suprimento sanguíneo após a secção e sem o restabelecimento da circulação brônquica após o transplante. Algumas técnicas foram propostas, ao longo dos anos, a fim de minimizar os problemas decorrentes do período isquêmico prolongado, como por exemplo, através da revascularização direta ou através da omentopexia, na qual a anastomose brônquica era revestida pelo grande omento promovendo a revascularização brônquica após o transplante (Coraud et al., 1992; Miller et al., 1993).

Além disso, o estímulo inflamatório nessa região após o procedimento cirúrgico pode levar à hipersecreção de muco, como discutido anteriormente. Segundo Allegra et al. (1989), a hipersecreção do muco pode ocasionar uma diminuição da freqüência de batimento ciliar durante a inflamação brônquica e produzir danos funcionais e estruturais ao aparato mucociliar.

Não observamos interação entre a droga e cirurgia sobre a freqüência de batimento ciliar. Tal interação poderia ocorrer e ser negativa caso a droga interferisse prejudicando o processo de cicatrização, o que parece não ter ocorrido. A literatura é controversa a respeito dos efeitos dos corticosteróides no processo de cicatrização. Auteri et al. (1992), não observaram prejuízo na cicatrização de brônquica de animais tratados com prednisona durante 28 dias pós-operatório. No entanto, outros trabalhos demonstram prejuízo no processo de cicatrização de animais tratados com corticosteróides a ponto desses medicamentos serem contra-indicados à pacientes na fila do transplante (McAnally et al., 2006). 


\section{Velocidade de Transporte Mucociliar}

A velocidade de transporte mucociliar in situ reflete o deslocamento de partículas ao longo do epitélio brônquico por unidade de tempo, constituindo uma medida direta da capacidade de depuração desse sistema. O transporte mucociliar normal depende de um grande número de fatores interrelacionados, dentre os quais podemos destacar a presença de um epitélio intacto com funcionamento ciliar coordenado, perfeita composição e tamanho da camada periciliar, bem como adequada quantidade de muco com propriedades viscoelásticas ideais (Albertini-Yagi 2005).

As alterações observadas na transportabilidade do muco dos animais tratados com prednisona poderiam indicar prejuízo na velocidade de transporte mucociliar. Apesar disso, não observamos efeitos funcionais na velocidade de transporte mucociliar nos grupos tratados com as dosagens mais baixas $(0,625 \mathrm{mg} / \mathrm{kg} / \mathrm{dia}$ e $1,25 \mathrm{mg} / \mathrm{kg} / \mathrm{dia})$. Observamos que a dosagem $2,5 \mathrm{mg} / \mathrm{kg} / \mathrm{dia}$ exerceu efeito negativo sobre esta variável, prejudicando a depuração mucociliar quando comparada com os animais do grupo controle e com os que receberam a dosagem de $0,625 \mathrm{mg} / \mathrm{kg} / \mathrm{dia}$.

Com relação à cirurgia de secção e anastomose, o processo de desnervação e isquemia a que o brônquio é submetido após a lesão resulta na diminuição da velocidade de transporte mucociliar (Xavier et al., 2007; Pazetti et al., 2008). A literatura mostra que os prejuízos decorrentes da secção e anastomose brônquica podem ser verificados em todo tecido adjacente à ferida cirúrgica. Estudos relatam que, após o transplante, o transporte mucociliar está diminuído e que há um aumento na rigidez do muco (Veale et al., 1993; Tomkiewicz et al., 1995; Pazetti et al., 2008). 
Neste trabalho confirmamos tal achado ao observar que a velocidade de transporte mucociliar foi prejudicada nos animais avaliados após 7 e 15 dias do procedimento cirúrgico. Xavier et al. (2007) observou prejuízo nesta variável em brônquios após a cirurgia de transplante pulmonar em ratos com tendência de recuperação deste parâmetro após 15 dias do procedimento cirúrgico e recuperação efetiva após 30 dias. Observamos, no presente trabalho, a recuperação desta variável após 30 dias da cirurgia.

O comportamento da VTMC foi semelhante aos resultados achados na análise da variável FBC. Tal resultado já era esperado uma vez que o bom funcionamento das duas variáveis está relacionado e depende da integridade do brônquio. Desta maneira, vale para esta variável a mesma discussão sobre as alterações na fisiologia brônquica (desnervação, isquemia e lesão do epitélio) que fizemos para analisar a FBC. Além das alterações na FBC, verificamos ainda que as características do muco estão alteradas nesses animais o que contribui para o prejuízo da VTMC.

\section{Depuração Mucociliar}

De maneira geral verificamos que a prednisona, apesar de prejudicar a transportabilidade do muco, não altera a depuração mucociliar. Apenas altas dosagens da droga podem, além de prejudicar a TM, diminuir a VTMC e conseqüentemente a depuração local.

Observamos que todos os grupos submetidos à cirurgia, apresentaram prejuízo nas três variáveis estudadas. Portanto podemos afirmar que a depuração mucociliar foi prejudicada pelo procedimento operatório. 
Tal resultado corrobora com a literatura disponível sobre o tema (Rivero et al., 2001; Pazetti et al., 2008).

Apesar da efetiva melhora na qualidade do muco dos animais que foram operados e tratados com prednisona, não podemos afirmar que a associação entre droga e intervenção cirúrgica interfira na depuração mucociliar, já que não foi verificada qualquer alteração na velocidade de transporte mucociliar nesses animais. 
- Apenas altas dosagens de prednisona prejudicam a depuração mucociliar.

- A terapia com prednisona associada à cirurgia de secção e anastomose brônquica não altera a depuração mucociliar visto que, apesar de melhorar a transportabilidade do muco, a freqüência de batimento ciliar e a velocidade de transporte mucociliar não são influenciadas. 
8 ANEXOS 
Anexo A - Valores individuais dos resultados obtidos na análise de FBC (Hertz), VTMC (mm/min), TM (s/ unidade)

\begin{tabular}{|c|c|c|c|c|}
\hline Grupo & Animais & FBC & VTMC & TM \\
\hline P1 - 7 dias & $\mathrm{R} 1$ & 9,15 & 0,76 & 0,66 \\
\hline P1 - 7 dias & $\mathrm{R} 2$ & 8,5 & 0,81 & 0,65 \\
\hline P1 - 7 dias & R3 & 7,36 & 0,54 & 0,81 \\
\hline P1 - 7 dias & $\mathrm{R} 4$ & 8,8 & 0,43 & 0,75 \\
\hline P1 - 7 dias & R5 & 9,39 & 0,38 & $\mathrm{MI}^{*}$ \\
\hline P1 - 7 dias & R6 & 9,44 & 0,56 & 0,85 \\
\hline P1 - 7 dias & $\mathrm{R} 7$ & 10,22 & 0,54 & 1,02 \\
\hline P1 - 7 dias & R8 & 11,21 & 0,61 & $M I^{*}$ \\
\hline P1 - 7 dias & R9 & 10,26 & 0,55 & 0,6 \\
\hline \multirow[t]{3}{*}{$\mathrm{P} 1-7$ dias } & R10 & 9,54 & 0,52 & 0,6 \\
\hline & Média & 9,39 & 0,57 & 0,74 \\
\hline & DP & 1,06 & 0,19 & 0,15 \\
\hline
\end{tabular}

\begin{tabular}{|c|c|c|c|c|}
\hline Grupo & Animais & FBC & VTMC & TM \\
\hline P2 - 7 dias & R1 & 8,5 & 0,66 & 0,92 \\
\hline P2 - 7 dias & $\mathrm{R} 2$ & 9,31 & 0,45 & $\mathrm{Ml}^{*}$ \\
\hline P2 - 7 dias & R3 & 8,54 & 0,5 & $\mathrm{Ml}^{*}$ \\
\hline P2 - 7 dias & $\mathrm{R} 4$ & 9,43 & 0,56 & 0,59 \\
\hline P2 - 7 dias & R5 & 7,18 & 0,47 & 0,87 \\
\hline P2 - 7 dias & R6 & 7,25 & 0,52 & 1,03 \\
\hline P2 - 7 dias & $\mathrm{R} 7$ & 8,11 & 0,5 & 0,83 \\
\hline P2 - 7 dias & R8 & 9,21 & 0,48 & 0,72 \\
\hline P2 - 7 dias & $\mathrm{R} 9$ & 6,54 & 0,67 & $\mathrm{Ml}^{*}$ \\
\hline \multirow[t]{3}{*}{$\mathrm{P} 2-7$ dias } & R10 & 9,68 & $\mathrm{NO}^{* *}$ & $\mathrm{Ml}^{*}$ \\
\hline & Média & 8,38 & 0,53 & 0,83 \\
\hline & DP & 1,08 & 0,08 & 0,15 \\
\hline
\end{tabular}

* MI= quantidade de muco coletado insuficiente para realização da análise

${ }^{* *} \mathrm{NO}=$ medida não observada 


\begin{tabular}{|c|c|c|c|c|}
\hline Grupo & Animais & FBC & VTMC & TM \\
\hline P3 - 7 dias & $\mathrm{R} 1$ & 8,45 & 1,22 & MI \\
\hline P3 - 7 dias & $\mathrm{R} 2$ & 9,64 & 0,48 & 0,67 \\
\hline P3 - 7 dias & R3 & 10,58 & 0,48 & MI \\
\hline P3 - 7 dias & $\mathrm{R} 4$ & 9,08 & 0,29 & 0,95 \\
\hline P3 - 7 dias & R5 & 8,31 & 0,27 & 0,77 \\
\hline P3 - 7 dias & R6 & 8,25 & 0,56 & $\mathrm{MI}$ \\
\hline $\mathrm{P} 3-7$ dias & $\mathrm{R} 7$ & 9,11 & 0,52 & 0,81 \\
\hline P3 - 7 dias & R8 & 11,54 & 0,42 & 0,63 \\
\hline P3 - 7 dias & R9 & 9,65 & 0,21 & 0,75 \\
\hline \multirow[t]{3}{*}{ P3 - 7 dias } & R10 & 9,22 & 0,32 & 0,8 \\
\hline & Média & 9,38 & 0,48 & 0,77 \\
\hline & DP & 1,04 & 0,39 & 0,10 \\
\hline
\end{tabular}

\begin{tabular}{|c|c|c|c|c|}
\hline Grupo & Animais & FBC & VTMC & TM \\
\hline ScP2 - 7 dias & $\mathrm{R} 1$ & 6,2 & $\mathrm{NO}^{* *}$ & 0,65 \\
\hline ScP2 -7 dias & $\mathrm{R} 2$ & 9,3 & 0,23 & 0,7 \\
\hline ScP2 -7 dias & R3 & 6,3 & 0,23 & 0,65 \\
\hline ScP2 - 7 dias & $\mathrm{R} 4$ & 5,6 & 0,25 & 0,66 \\
\hline ScP2 -7 dias & R5 & $\mathrm{NO} * *$ & 0,32 & 0,56 \\
\hline ScP2 -7 dias & R6 & $\mathrm{NO}^{* *}$ & 0,19 & 0,48 \\
\hline ScP2 - 7 dias & $\mathrm{R} 7$ & 8,21 & 0,22 & 0,84 \\
\hline ScP2 -7 dias & R8 & 5,48 & 0,24 & 0,68 \\
\hline ScP2 -7 dias & R9 & 6,25 & 0,42 & 0,72 \\
\hline \multirow[t]{3}{*}{ ScP2 -7 dias } & R10 & 5,21 & 0,31 & 0,44 \\
\hline & Média & 6,85 & 0,27 & 0,64 \\
\hline & DP & 1,66 & 0,01 & 0,12 \\
\hline
\end{tabular}

* $\mathrm{Ml}=$ quantidade de muco coletado insuficiente para realização da análise

${ }^{* *} \mathrm{NO}=$ medida não observada 


\begin{tabular}{ccccc}
\hline Grupo & Animais & FBC & VTMC & TM \\
\hline ScSal - 7 dias & R1 & 7,82 & 0,31 & 0,52 \\
ScSal - 7 dias & R2 & 7,53 & 0,29 & 0,6 \\
ScSal - 7 dias & R3 & 8,21 & 0,32 & 0,54 \\
ScSal - 7 dias & R4 & 7,21 & 0,28 & MI $^{*}$ \\
ScSal - 7 dias & R5 & 8,65 & 0,28 & 0,54 \\
ScSal - 7 dias & R6 & 7,6 & 0,3 & 0,59 \\
ScSal - 7 dias & R7 & 8,82 & 0,29 & 0,68 \\
ScSal - 7 dias & R8 & 8,11 & 0,33 & MI* \\
ScSal - 7 dias & R9 & 8,2 & 0,28 & 0,62 \\
ScSal - 7 dias & R10 & 7,12 & 0,32 & 0,52 \\
\hline & Média & $\mathbf{7 , 9 3}$ & $\mathbf{0 , 3 0}$ & $\mathbf{0 , 5 8}$ \\
& DP & $\mathbf{0 , 5 7}$ & $\mathbf{0 , 0 2}$ & $\mathbf{0 , 0 6}$ \\
\hline
\end{tabular}

\begin{tabular}{lcccc}
\hline Grupo & Animais & FBC & VTMC & TM \\
\hline Sal - 7 dias & R1 & 9,48 & 0,56 & 0,95 \\
Sal - 7 dias & R2 & 10,22 & 0,7 & 0,91 \\
Sal - 7 dias & R3 & NO $^{* *}$ & $N^{* *}$ & 0,91 \\
Sal - 7 dias & R4 & 9,12 & 0,61 & 0,98 \\
Sal - 7 dias & R5 & 9,88 & 0,57 & 0,93 \\
Sal - 7 dias & R6 & 9,1 & 0,59 & 0,93 \\
Sal - 7 dias & R7 & 9,02 & 0,6 & 0,92 \\
Sal - 7 dias & R8 & 10,56 & 0,72 & 0,92 \\
Sal - 7 dias & R9 & 9,21 & 0,68 & 1,01 \\
Sal - 7 dias & R10 & 9,54 & 0,53 & 0,95 \\
\hline & Média & $\mathbf{9 , 5 7}$ & $\mathbf{0 , 6 2}$ & $\mathbf{0 , 9 4}$ \\
& DP & $\mathbf{0 , 5 4}$ & $\mathbf{0 , 0 7}$ & $\mathbf{0 , 0 3}$ \\
\hline
\end{tabular}

* Ml= quantidade de muco coletado insuficiente para realização da análise

${ }^{* *} \mathrm{NO}=$ medida não observada 


\begin{tabular}{|c|c|c|c|c|}
\hline Grupo & Animais & FBC & VTMC & TM \\
\hline$P 1-15$ dias & $\mathrm{R} 1$ & 10,3 & $\mathrm{NO}^{* *}$ & 0,88 \\
\hline$P 1-15$ dias & $\mathrm{R} 2$ & 11,02 & 0,8 & 0,7 \\
\hline $\mathrm{P} 1-15$ dias & R3 & 9,65 & 0,33 & 0,51 \\
\hline $\mathrm{P} 1-15$ dias & $\mathrm{R} 4$ & 10,52 & 0,37 & 0,35 \\
\hline $\mathrm{P} 1-15$ dias & R5 & 8,54 & 0,72 & 0,49 \\
\hline $\mathrm{P} 1-15$ dias & R6 & 9,58 & 0,61 & 0,9 \\
\hline $\mathrm{P} 1-15$ dias & $\mathrm{R} 7$ & 10,22 & 0,84 & MI \\
\hline$P 1-15$ dias & $\mathrm{R} 8$ & 9,88 & 0,63 & 0,81 \\
\hline $\mathrm{P} 1-15$ dias & $\mathrm{R} 9$ & 10,11 & 0,76 & 1,23 \\
\hline \multirow[t]{3}{*}{$P 1-15$ dias } & R10 & 10,2 & 0,7 & 1,04 \\
\hline & Média & 10,00 & 0,64 & 0,77 \\
\hline & DP & 0,66 & 0,18 & 0,28 \\
\hline
\end{tabular}

\begin{tabular}{ccccc}
\hline Grupo & Animais & FBC & VTMC & TM \\
\hline P2 -15 dias & R1 & 8,74 & 0,66 & 0,67 \\
P2 - 15 dias & R2 & 8,54 & 0,59 & 0,62 \\
P2 - 15 dias & R3 & 10,91 & 0,9 & 0,79 \\
P2 - 15 dias & R4 & 11 & 0,75 & 0,7 \\
P2 -15 dias & R5 & 9,22 & 0,62 & 0,86 \\
P2 -15 dias & R6 & 8,14 & 0,66 & 1,03 \\
P2 -15 dias & R7 & 9,17 & 0,64 & MI $^{*}$ \\
P2 -15 dias & R8 & 9,55 & 0,52 & 1,04 \\
P2 -15 dias & R9 & 10,11 & 0,68 & 0,9 \\
P2 -15 dias & R10 & NO** & NO** & 0,96 \\
\hline & Média & $\mathbf{9 , 4 9}$ & $\mathbf{0 , 6 7}$ & $\mathbf{0 , 8 4}$ \\
& DP & $\mathbf{1 , 0 1}$ & $\mathbf{0 , 1 1}$ & $\mathbf{0 , 1 6}$ \\
\hline
\end{tabular}

* $\mathrm{Ml}=$ quantidade de muco coletado insuficiente para realização da análise

${ }^{* *} \mathrm{NO}=$ medida não observada 


\begin{tabular}{ccccc}
\hline Grupo & Animais & FBC & VTMC & TM \\
\hline P3 - 15 dias & R1 & 11,09 & 0,53 & 0,73 \\
P3 - 15 dias & R2 & 8,42 & 0,59 & 0,64 \\
P3 - 15 dias & R3 & 9,92 & 0,36 & 0,73 \\
P3 - 15 dias & R4 & 8,43 & 0,63 & 0,69 \\
P3 - 15 dias & R5 & 9,87 & 0,67 & 1,06 \\
P3 - 15 dias & R6 & 8,11 & 0,52 & \\
P3 - 15 dias & R7 & 8,44 & 0,48 & 0,71 \\
P3 - 15 dias & R8 & 6,12 & 0,52 & 0,88 \\
P3 - 15 dias & R9 & 8,55 & 0,65 & 0,95 \\
P3 - 15 dias & R10 & 8,14 & 0,44 & 0,82 \\
\hline & Média & $\mathbf{8 , 7 1}$ & $\mathbf{0 , 5 4}$ & $\mathbf{0 , 8 0}$ \\
& DP & $\mathbf{1 , 3 4}$ & $\mathbf{0 , 1 0}$ & $\mathbf{0 , 1 4}$ \\
\hline
\end{tabular}

\begin{tabular}{ccccc}
\hline Grupo & Animais & FBC & VTMC & TM \\
\hline ScP2 -15 dias & R1 & 6,1 & 0.3 & 0,95 \\
ScP2 -15 dias & R2 & 5,3 & 0,36 & 0,87 \\
ScP2 -15 dias & R3 & 6,7 & 0,19 & 0,87 \\
ScP2 -15 dias & R4 & 5,3 & 0,12 & 0,57 \\
ScP2 -15 dias & R5 & 5,7 & 0,16 & \\
ScP2 -15 dias & R6 & 9,14 & 0,55 & 0,56 \\
ScP2 -15 dias & R7 & 8,11 & 0,46 & 1,08 \\
ScP2 -15 dias & R8 & 7,18 & 0,25 & 0,85 \\
ScP2 -15 dias & R9 & & 0,25 & 0,78 \\
ScP2 -15 dias & R10 & 6,3 & 0,34 & 0,7 \\
\hline & Média & $\mathbf{6 , 6 9}$ & $\mathbf{0 , 3 0}$ & $\mathbf{0 , 8 0}$ \\
& DP & $\mathbf{1 , 3 9}$ & $\mathbf{0 , 1 4}$ & $\mathbf{0 , 1 7}$ \\
\hline
\end{tabular}

* $\mathrm{Ml}=$ quantidade de muco coletado insuficiente para realização da análise

${ }^{* *} \mathrm{NO}=$ medida não observada 


\begin{tabular}{ccccc}
\hline Grupo & Animais & FBC & VTMC & TM \\
\hline ScSal-15dias & R1 & 6,3 & 0,29 & 0,89 \\
ScSal-15dias & R2 & 6,21 & 0,3 & 1,01 \\
ScSal-15dias & R3 & 7,22 & 0,29 & 0,78 \\
ScSal-15dias & R4 & 7,21 & 0,31 & \\
ScSal-15dias & R5 & 6,58 & 0,32 & 0,94 \\
ScSal-15dias & R6 & 7,23 & 0,28 & 0,82 \\
ScSal-15dias & R7 & 6,98 & 0,3 & 0,86 \\
ScSal-15dias & R8 & 7,5 & 0,26 & 0,91 \\
ScSal-15dias & R9 & 7,21 & 0,26 & 0,95 \\
ScSal-15dias & R10 & 7,45 & 0,34 & \\
\hline & Média & $\mathbf{6 , 9 9}$ & $\mathbf{0 , 3 0}$ & $\mathbf{0 , 9 0}$ \\
& DP & $\mathbf{0 , 4 6}$ & $\mathbf{0 , 0 3}$ & $\mathbf{0 , 0 7}$ \\
\hline
\end{tabular}

\begin{tabular}{ccccc}
\hline Grupo & Animais & FBC & VTMC & TM \\
\hline Sal - 15 dias & R1 & 9,1 & 0,49 & 0,95 \\
Sal - 15 dias & R2 & 10,23 & 0,66 & 0,91 \\
Sal - 15 dias & R3 & 9,22 & 0,54 & 0,96 \\
Sal - 15 dias & R4 & 10,88 & 0,7 & 0,98 \\
Sal - 15 dias & R5 & 9,8 & 0,68 & 0,96 \\
Sal - 15 dias & R6 & & & 1,01 \\
Sal - 15 dias & R7 & 9,1 & 0,57 & 0,91 \\
Sal - 15 dias & R8 & 9,22 & 0,59 & 0,92 \\
Sal - 15 dias & R9 & 9,12 & & 0,93 \\
Sal - 15 dias & R10 & 10,2 & 0,63 & 0,89 \\
\hline & Média & $\mathbf{9 , 4 1}$ & $\mathbf{0 , 6 1}$ & $\mathbf{0 , 9 4}$ \\
& DP & $\mathbf{0 , 6 5}$ & $\mathbf{0 , 0 7}$ & $\mathbf{0 , 0 4}$ \\
\hline
\end{tabular}

* $\mathrm{Ml}=$ quantidade de muco coletado insuficiente para realização da análise

** $\mathrm{NO}=$ medida não observada 


\begin{tabular}{ccccc}
\hline Grupo & Animais & FBC & VTMC & TM \\
\hline P1 - 30 dias & R1 & 11,82 & 0,59 & 0,88 \\
P1 - 30 dias & R2 & 11,28 & 0,61 & 0,68 \\
P1 - 30 dias & R3 & & & 1,5 \\
P1 - 30 dias & R4 & 10,98 & 0,68 & 0,88 \\
P1 - 30 dias & R5 & 9,77 & 0,38 & 0,57 \\
P1 - 30 dias & R6 & 9,13 & 0,51 & 0,71 \\
P1 - 30 dias & R7 & 8,52 & 0,7 & 0,82 \\
P1 - 30 dias & R8 & 9,78 & 0,56 & \\
P1 - 30 dias & R9 & 8,12 & 0,65 & 0,73 \\
P1 - 30 dias & R10 & 8,4 & 0,58 & 0,66 \\
\hline & Média & $\mathbf{9 , 7 6}$ & $\mathbf{0 , 5 8}$ & $\mathbf{0 , 8 3}$ \\
& DP & $\mathbf{1 , 3 5}$ & $\mathbf{0 , 1 0}$ & $\mathbf{0 , 2 7}$ \\
\hline
\end{tabular}

\begin{tabular}{ccccc}
\hline Grupo & Animais & FBC & VTMC & TM \\
\hline P2 -30 dias & R1 & 10,8 & 0,59 & 0,67 \\
P2 -30 dias & R2 & 7,51 & 0,69 & 0,81 \\
P2 -30 dias & R3 & 9,45 & 0,54 & 1 \\
P2 -30 dias & R4 & 10,32 & 0,75 & 0,61 \\
P2 -30 dias & R5 & 10,45 & 0,55 & 0,74 \\
P2 -30 dias & R6 & 10,5 & 0,64 & 0,23 \\
P2 -30 dias & R7 & 9,24 & 0,42 & 0,64 \\
P2 -30 dias & R8 & 9,11 & 0,25 & 0,62 \\
P2 -30 dias & R9 & 9,75 & 0,7 & 0,81 \\
P2 -30 dias & R10 & 10,05 & 0,58 & \\
\hline & Média & $\mathbf{9 , 7 2}$ & $\mathbf{0 , 5 7}$ & $\mathbf{0 , 6 8}$ \\
& DP & $\mathbf{0 , 9 6}$ & $\mathbf{0 , 1 5}$ & $\mathbf{0 , 2 1}$ \\
\hline
\end{tabular}

* $\mathrm{Ml}=$ quantidade de muco coletado insuficiente para realização da análise

${ }^{* *} \mathrm{NO}=$ medida não observada 


\begin{tabular}{ccccc}
\hline Grupo & Animais & FBC & VTMC & TM \\
\hline P3 - 30 dias & R1 & 8,8 & 0,79 & 0,38 \\
P3 - 30 dias & R2 & 8,31 & 0,69 & 1,07 \\
P3 - 30 dias & R3 & 10,1 & 0,31 & 0,96 \\
P3 - 30 dias & R4 & 8,61 & 0,48 & 1,15 \\
P3 - 30 dias & R5 & 9,64 & 0,57 & 0,43 \\
P3 - 30 dias & R6 & 9,21 & 0,64 & 0,69 \\
P3 - 30 dias & R7 & 10,21 & 0,47 & 1,04 \\
P3 - 30 dias & R8 & 9,54 & 0,56 & \\
P3 - 30 dias & R9 & 8,22 & 0,42 & 0,75 \\
P3 - 30 dias & R10 & 11,2 & 0,32 & 0,59 \\
\hline & Média & $\mathbf{9 , 3 8}$ & $\mathbf{0 , 5 3}$ & $\mathbf{0 , 7 8}$ \\
& DP & $\mathbf{0 , 9 5}$ & $\mathbf{0 , 1 6}$ & $\mathbf{0 , 2 8}$ \\
\hline
\end{tabular}

\begin{tabular}{ccccc}
\hline Grupo & Animais & FBC & VTMC & TM \\
\hline ScP2 -30 dias & R1 & 9,24 & 0,46 & 0,83 \\
ScP2 -30 dias & R2 & 8,15 & 0,63 & 0,53 \\
ScP2 -30 dias & R3 & 7,11 & 0,94 & 0,62 \\
ScP2 -30 dias & R4 & 8,44 & & 0,61 \\
ScP2 -30 dias & R5 & 8,26 & 0,44 & \\
ScP2 -30 dias & R6 & 9,11 & 0,55 & 0,53 \\
ScP2 -30 dias & R7 & 8,56 & 0,52 & 0,78 \\
ScP2 -30 dias & R8 & 9,54 & 0,44 & \\
ScP2 -30 dias & R9 & 9,21 & 0,32 & 0,84 \\
ScP2 -30 dias & R10 & 10,06 & 0,4 & 0,47 \\
\hline & Média & $\mathbf{8 , 7 7}$ & $\mathbf{0 , 5 2}$ & $\mathbf{0 , 6 5}$ \\
& DP & $\mathbf{0 , 8 4}$ & $\mathbf{0 , 1 8}$ & $\mathbf{0 , 1 5}$ \\
\hline
\end{tabular}

* $\mathrm{Ml}=$ quantidade de muco coletado insuficiente para realização da análise

${ }^{* *} \mathrm{NO}=$ medida não observada 


\begin{tabular}{ccccc}
\hline Grupo & Animais & FBC & VTMC & TM \\
\hline ScSal-30dias & R1 & 8,56 & 0,7 & 0,52 \\
ScSal -30dias & R2 & 6,88 & 0,66 & 0,45 \\
ScSal-30dias & R3 & 7,21 & 0,54 & 0,68 \\
ScSal -30dias & R4 & 8,16 & 0,66 & 0,58 \\
ScSal -30dias & R5 & 6,55 & 0,48 & 0,54 \\
ScSal -30dias & R6 & 8,16 & 0,45 & 0,48 \\
ScSal-30dias & R7 & 8,23 & 0,51 & 0,56 \\
ScSal -30dias & R8 & 9,41 & 0,49 & 0,54 \\
ScSal-30dias & R9 & 8,65 & 0,41 & 0,53 \\
ScSal -30dias & R10 & 8,84 & 0,5 & 0,49 \\
\hline & Média & $\mathbf{8 , 0 7}$ & $\mathbf{0 , 5 4}$ & $\mathbf{0 , 5 4}$ \\
& DP & $\mathbf{0 , 9 1}$ & $\mathbf{0 , 1 0}$ & $\mathbf{0 , 0 6}$ \\
\hline
\end{tabular}

\begin{tabular}{ccccc}
\hline Grupo & Animais & FBC & VTMC & TM \\
\hline Sal - 30 dias & R1 & 9,87 & 0,59 & 0,78 \\
Sal - 30 dias & R2 & 10,1 & 0,67 & 0,56 \\
Sal - 30 dias & R3 & 8,5 & 0,59 & 0,93 \\
Sal - 30 dias & R4 & 9,6 & 0,63 & 0,98 \\
Sal - 30 dias & R5 & 11,26 & 0,83 & 1,05 \\
Sal - 30 dias & R6 & 11,45 & 0,61 & MI \\
Sal - 30 dias & R7 & 9,1 & 0,55 & 1,22 \\
Sal - 30 dias & R8 & 8,26 & 0,62 & 1,02 \\
Sal - 30 dias & R9 & 8,24 & 0,57 & MI \\
Sal - 30 dias & R10 & 9,21 & 0,44 & 0,79 \\
\hline & Média & $\mathbf{9 , 5 6}$ & $\mathbf{0 , 6 1}$ & $\mathbf{0 , 9 2}$ \\
& DP & $\mathbf{1 , 1 4}$ & $\mathbf{0 , 1 0}$ & $\mathbf{0 , 2 0}$ \\
\hline
\end{tabular}

* MI= quantidade de muco coletado insuficiente para realização da análise

${ }^{* *} \mathrm{NO}=$ medida não observada 
Anexo B - Valores da significância e intervalo de confiança obtidos das comparações múltiplas ( teste: Bonferroni)

\begin{tabular}{|c|c|c|c|c|c|}
\hline \multicolumn{3}{|c|}{$\begin{array}{l}\text { Variável: } \\
\text { Freqüência de Batimento Ciliar }\end{array}$} & \multirow{2}{*}{ Significância } & \multicolumn{2}{|c|}{$\begin{array}{c}\text { Intervalo de } \\
\text { confiança (95\%) }\end{array}$} \\
\hline \multicolumn{3}{|c|}{ Grupos } & & Mínimo & Máximo \\
\hline P1 -7 dias & vs & P1-15 dias & 0,60 & $-1,81$ & 0,58 \\
\hline P1 -7 dias & vs & P1 - 30 dias & 1,00 & $-1,60$ & 0,86 \\
\hline P1-15 dias & vs & P1 - 30 dias & 1,00 & $-0,99$ & 1,48 \\
\hline P2 -7 dias & vs & P2 -15 dias & 0,08 & $-2,31$ & 0,09 \\
\hline P2 -7 dias & vs & P2 - 30 dias & 0,02 & $-2,51$ & $-0,18$ \\
\hline P2 -15 dias & vs & P2 - 30 dias & 1,00 & $-1,43$ & 0,97 \\
\hline P3 - 7 dias & vs & P3 - 15 dias & 0,57 & $-0,61$ & 1,95 \\
\hline P3 - 7 dias & vs & P3 - 30 dias & 1,00 & $-1,28$ & 1,28 \\
\hline P3 - 15 dias & vs & P3 - 30 dias & 0,57 & $-0,60$ & 1,95 \\
\hline P2Sc - 7 dias & vs & P2Sc - 15 dias & 1,00 & $-1,58$ & 1,42 \\
\hline P2Sc - 7 dias & vs & P2Sc - 30 dias & 0,00 & $-3,66$ & $-0,74$ \\
\hline P2Sc - 15 dias & vs & P2Sc - 30 dias & 0,00 & $-3,54$ & $-0,71$ \\
\hline SalSc - 7 dias & vs & SalSc - 15 dias & 0,01 & 0,17 & 1,71 \\
\hline SalSc - 7 dias & vs & SalSc - 30 dias & 1,00 & $-0,91$ & 0,63 \\
\hline SalSc -15 dias & vs & SalSc - 30 dias & 0,00 & $-1,85$ & $-0,30$ \\
\hline Sal -7 dias & vs & Sal - 15 dias & 1,000 & $-1,095$ & 0,931 \\
\hline Sal -7 dias & vs & Sal - 30 dias & 1,000 & $-0,976$ & 0,998 \\
\hline Sal - 15 dias & vs & Sal - 30 dias & 1,000 & $-0,894$ & 1,081 \\
\hline
\end{tabular}




\begin{tabular}{|c|c|c|c|c|c|}
\hline \multicolumn{3}{|c|}{$\begin{array}{l}\text { Variável: } \\
\text { Velocidade de Transporte Mucociliar }\end{array}$} & \multirow{2}{*}{ Significância } & \multicolumn{2}{|c|}{$\begin{array}{c}\text { Intervalo de } \\
\text { confiança (95\%) }\end{array}$} \\
\hline \multicolumn{3}{|c|}{ Grupos } & & Mínimo & Máximo \\
\hline P1 -7 dias & vs & P1-15 dias & 0,86 & $-0,24$ & 0,10 \\
\hline P1 -7 dias & vs & P1 - 30 dias & 1,00 & $-0,18$ & 0,15 \\
\hline P1 -15 dias & vs & P1 - 30 dias & 1,00 & $-0,11$ & 0,23 \\
\hline P2 -7 dias & vs & P2 -15 dias & 0,06 & $-0,28$ & 0,01 \\
\hline P2 -7 dias & vs & P2 - 30 dias & 1,00 & $-0,17$ & 0,10 \\
\hline P2 -15 dias & vs & P2 - 30 dias & 0,24 & $-0,04$ & 0,24 \\
\hline P3 - 7 dias & vs & P3 - 15 dias & 1,00 & $-0,29$ & 0,16 \\
\hline P3 - 7 dias & vs & P3 - 30 dias & 1,00 & $-0,27$ & 0,18 \\
\hline P3 - 15 dias & vs & P3 - 30 dias & 1,00 & $-0,21$ & 0,24 \\
\hline P2Sc - 7 dias & vs & P2Sc - 15 dias & 1,00 & $-0,19$ & 0,13 \\
\hline P2Sc - 7 dias & vs & P2Sc - 30 dias & 0,00 & $-0,42$ & $-0,09$ \\
\hline P2Sc - 15 dias & vs & P2Sc - 30 dias & 0,00 & $-0,38$ & $-0,06$ \\
\hline SalSc - 7 dias & vs & SalSc - 15 dias & 1,00 & $-0,06$ & 0,07 \\
\hline SalSc - 7 dias & vs & SalSc - 30 dias & 0,00 & $-0,31$ & $-0,17$ \\
\hline SalSc -15 dias & vs & SalSc - 30 dias & 0,00 & $-0,31$ & $-0,18$ \\
\hline Sal -7 dias & vs & Sal - 15 dias & 1,00 & $-0,09$ & 0,11 \\
\hline Sal -7 dias & vs & Sal - 30 dias & 1,00 & $-0,09$ & 0,10 \\
\hline Sal - 15 dias & vs & Sal - 30 dias & 1,00 & $-0,10$ & 0,10 \\
\hline
\end{tabular}




\begin{tabular}{|c|c|c|c|c|c|}
\hline \multicolumn{3}{|c|}{$\begin{array}{l}\text { Variável: } \\
\text { Transportabilidade do muco “in vitro" }\end{array}$} & \multirow{2}{*}{ Significância } & \multicolumn{2}{|c|}{$\begin{array}{c}\text { Intervalo de } \\
\text { confiança }(95 \%)\end{array}$} \\
\hline \multicolumn{3}{|c|}{ Grupos } & & Mínimo & Máximo \\
\hline P1 -7 dias & vs & P1-15 dias & 1,00 & $-0,33$ & 0,28 \\
\hline P1 -7 dias & vs & P1 - 30 dias & 1,00 & $-0,39$ & 0,23 \\
\hline P1 -15 dias & vs & P1 - 30 dias & 1,00 & $-0,36$ & 0,24 \\
\hline P2 -7 dias & vs & P2 -15 dias & 1,00 & $-0,26$ & 0,23 \\
\hline P2 -7 dias & vs & P2 - 30 dias & 0,41 & $-0,10$ & 0,39 \\
\hline P2 -15 dias & vs & $\mathrm{P} 2$ - 30 dias & 0,21 & $-0,06$ & 0,38 \\
\hline P3 - 7 dias & vs & P3 - 15 dias & 1,000 & $-0,302$ & 0,205 \\
\hline P3 - 7 dias & vs & P3 - 30 dias & 1,000 & $-0,275$ & 0,243 \\
\hline P3 - 15 dias & vs & P3 - 30 dias & 1,000 & $-0,204$ & 0,269 \\
\hline P2Sc - 7 dias & vs & P2Sc - 15 dias & 0,06 & $-0,34$ & 0,01 \\
\hline P2Sc - 7 dias & vs & P2Sc - 30 dias & 1,00 & $-0,19$ & 0,16 \\
\hline P2Sc - 15 dias & vs & P2Sc - 30 dias & 0,12 & $-0,03$ & 0,33 \\
\hline SalSc - 7 dias & vs & SalSc - 15 dias & 1,00 & $-0,08$ & 0,08 \\
\hline SalSc - 7 dias & vs & SalSc - 30 dias & 0,53 & $-0,03$ & 0,11 \\
\hline SalSc -15 dias & vs & SalSc - 30 dias & 0,53 & $-0,03$ & 0,11 \\
\hline Sal -7 dias & vs & Sal - 15 dias & 1,00 & $-0,13$ & 0,13 \\
\hline Sal -7 dias & vs & Sal - 30 dias & 1,00 & $-0,11$ & 0,16 \\
\hline Sal - 15 dias & vs & Sal - 30 dias & 1,00 & $-0,11$ & 0,16 \\
\hline
\end{tabular}


Adrian VS. Imunogenetics and genomics. Lancet. 2001; 357: 2037-41.

Aeba R, Stout SE, Francalancia NA, Keenan RJ, Duncan AJ, Yousem SA, Burckart GJ, Griffith BP. Aspects of lung transplantation that contribute to increased severity of pneumonia. An experimental study. J Thorac Cardiovasc Surg.1993;106:449-457.

Agnew JE, Bateman JRM, Pavia D, Clarke SW. Peripheral airways mucus clearance in stable asthma is improved by oral corticosteroid therapy. Bull Eur Physiopath Resp 1984; 20: 295-301.

Agnew JE, Bateman JRM, Sheahan NF, Lennard-Jones AM, Pavia D, Clarke SW. Effects of oral corticosteroids on mucus clearance by cough and mucociliary transport in stable asthma. Bull Eur Ohysiopath Respir 1983; 19:37-41.

Agu RU, Jorissen M, Willems T, Van den Mooter G, Kinget R, Augustinjns P. Effects of pharmaceutical compounds on ciliary beating in human nasal epithelial cells: a comparative study of cell culture models. Pharm Res. 1999; 16:1380-1385.

Allegra L Fabbri LM, Picotti G, Matolli S. Bronchial epithelium and asthma. Eur Respir J Suppl. 1989: 6:460s-468s.

Andersen IB, Proctor DF, Camner P, Jensen PL, Philipson K. Nasal clearance in monozygotic twins. Am Rev Respir Dis 1974; 110: 301-5.

Aquino ES. Efeitos da solução salina hipertônica (7\%) associada à pressão positiva (CPAP) sobre o transporte mucociliar nasal e muco respiratório em indivíduos portadores de fibrose cística [tese]. São Paulo: Faculadade de Medicina, Universidade de São Paulo; 2009. 
Arumugan S, Nimmannit SD. The effect of immunosuppression on wound healing. Surg Gynecol Obstet.1971;133:72-74.

Auteri JS, Jeevanandam V, Sánchez JA, Marboe CC, Smith CR. Normal bronchial healing without bronchialwrapping in canine lung transplantation. Ann Thorac Surg 1992;53:80-84.

AVMA Panel on Euthanasia. American Veterinary Medical Association. 2000 Report of the AVMA Panel on Euthanasia. $J$ Am Vet Med Assoc. 2001;218(5):669-96.

Barroso FC, Lorenzi-Filho G, Carvalho CR, Pimentel M, Boueri FV, BarbasFilho JV. Transporte de eletrólitos no epitélio respiratório dos portadores de fibrose cística. Rev Hosp Clin Fac Méd São Paulo. 1992; 47 (2):76-8.

Benfield JR, Wain JC. The history of lung transplantation. Chest Surg Clin Am. 2000;10:189-99.

Berg OH, Lie K, Steinsvag SK. The effects of topical nasal steroids on rat respiratory mucosa in vivo, with special reference to benzalkonium chloride. Allergy.1997;52(6):627-32.

Bier BE. Advances in imunossupression: biology molecular actions, and clinical implications. Curr Open Hematol 1993;10:149-59.

Braat JP, Ainge G, Bowles JA, Richards DH, Van Riessen D, Visser WJ, Rijnties E. The lack of effect of benzalkonium chloride on the cilia of the nasal mucosa in patients with perennial allergic rhinitis: a combined functional, light, scanning and transmission electron microscopy study. Clin Exp Allergy. 1995;25(10):957-65

Bradbury j. Human major histocompatibility complex sequenced. Lancet. 1999; 354:1531. 
Braga PC. Methods for investigation of mucus: multidisciplinary approach. Allegra L, Braga PC. eds. Bronchial mucology and related diseases. New York: Raven Press. 1990; 13-26.

Brody JS, Klempfner G, Staum MM, Vidyasagar D, Kuhl DE, Waldhausen JA. Mucociliary clearence after lung deneration and bronchial section. $J$ Appl Physiol. 1972; 32(2): 160-4.

Bush A, Payne D, Pike S, Jenkins G, Henke MO, Rubin BK. Mucus properties in children with primary ciliary dyskinesia: comparison with cystic fibrosis. Chest. 2006: 129(1); 118-23.

Calne RY, Rolles K, White DJG, Thirn S, Evans DB, McMaster P, Dunn DC, Craddock GN, Henderson RG, Aziz S, Lewis P, Cyclosporin A as the only immunossupressant in 34 recipients of cadaver organs: 32 Kdneys, 2 pâncreas and 2 livers. Lancet. 1979; 2: 1033-36.

Camargo JJ, Rocha MG, Oliveira ME, Godoy DV. Transplante isolado de pulmão: relato do primeiro caso realizado na América do Sul. J Pneumol 1990;16(supl.1):9.

Carvalho CRR. Fisiopatología Respiratória. São Paulo: Ed Atheneu; 1999.

Castro M. Efeitos Aniinflamatórios e Antiproliferativos dos glicocorticóides: Concordância ou Discordância?. Arq Brás Endocrinol Metab. 2005; 49(3):334-336.

Chaparro C, Maurer J, Gutierrez C. Infection with Burkholderia cepacia in Cystic Fibrosis - Outcome Following Lung Transplantation. Am J Respir Crit Care Med 2001; 163: 43-48.

Charmandari E, Kino T, Chrousos GP. Glucocorticoids and their actions: an introduction. Ann NY Acad Sci. 2004; 1024:1-8. 
Chhajed PN, Tamm M, Malouf MA, Glanville AR. Lung transplantation: management and complications. Indian $J$ Chest Dis Allied Sci. 2002;44(1):31-43. [Abstract, PubMed ID 11845931].

Chilvers MA, Rutman A, O Callaghan. Ciliary beat pattern is associated with specific ultrastructural defects in primary ciliary dyskinesia. J Allergy Clin Immunol 2003;112(3):518-24.

Christie JD, Edwards LB, Aurora P, Dobbels F, Kirk R, Rahmel AO, et al. The Registry of the InternationalSociety for Heart and Lung Transplantation: twenty-sixth official adult lung and heart-lung transplantation report - 2009 . J Heart Lung Transplant. 2009;28:1031-49.

Christie JD, van Raemdonck D, de Perrot M, Barr M, Keshavjee S, Arcasoy $S$, Orens J. Report of the ISHLT Working group on primary lung graft dysfunction Part I: Introdution and Methods. J Heart Lung Transplant 2005;24:1451.

Clarck AR. Anti-inflamatory functions of glucocorticoid-induced genes. Mol Cell Endocrinol. 2007;275(1-2):79-97.

Couraud LC, Baudet E, Martigne C, Roques X, Velly JF, Laborde N, Dubrey J, Clerc F,Dromer C,Vallieres E. Bronchial revascularization in double-lung transplantation: a series of 8 patients. Ann Thorac Surg.1992;53:88-94

Damiani D, Kuperman H, Dichtchekenian V, Manna TD, Setian N. Repercussions of corticotherapy: The cost-bennefit ratio. Rev Pediatria. 2001;1:71-82.

Doherty PS, Jasso-Victoria R, Zúñiga RO, Ramirez JLA, Cantón BV, Veja AS, Lopez VR, Ávila G G. Efecto de la prednisona, la azatioprina y la ciclosporina A sobre la cicatrización bronquial. Cir Ciruj. 1998; 66: 165-71. 
Dong VM, Womer KL, Sayegh MH. Transplantation tolerance: the concept and its applicability. Pediatr Transplant. 1999;3:181-92.

Duchateau GS, Zudeima J, Merkus FW. The in vitro and in vivo effect of a new non-halogenated corticosteroid - budesonide - aerosol on human ciliary epithelial function. Allergy. 1986; 41(4): 260-5

Fan Y, Xiao Y B, Weng Y G. Tacrolimus Versus Cyclosporine for Adult Lung Transplant Recipients: A Meta-Analysis.Transplantation Proceedings. 2009; 41:1821-1824.

Fernandes PM, Said MM, Pazetti R, Moreira LF, Jatene FB. Effects of azathioprine on mucociliary clearance after bronchial section and anastomosis in a rat experimental model. J Bras Pneumol 2008;34(5):273-9.

Fraser RS, Colman N, Muller NL, Paré PD. Frase and Paré's diagnosis of diseases of the chest. 4th ed. Philadelphia: W.B. Saunders, 1999;2077-166.

Golberg M, Lima O, Cooper JD. A comparison betwen cyclosporin A and and Methilprednisolone plus azatioprine on bronchial healing folowing canine lung autotransplantation. JThorac Cardiovasc Surg 1983;85: 21-26.

Hardy JD, EraslanS, Daltoo LM. Autotransplant and homotransplantations of the lung. J Thorac Cardiovasc Surg 1963; 46:606.

Hardy, JD. The first lung transplant in man (1963) and the first heart transplant in man (1964). Transplant Proc. 1999;31:25-9.

Hartigan PM, Pedoto A. Anesthetic considerations for lung volume reduction surgery and lung transplantation. Thorac Surg Clin. 2005;15(1):143-57.

Hartman FA, Brownell KA. The hormone of the adrenal cortex. Science.1930;72:76. 
Hertz M I, Aurora P, Christie JD, et al. Registry of the International Society for Heart and Lung Transplantation: A Quarter Century of Thoracic Transplantation. J Heart Lung Transplant. 2008;27:937-42.

Hofmann T, Wolf G, Koidl B. Effect of topical corticosteroids and topical antihistaminics on ciliary epithelium of human nasal mucosa in vitro. HNO.1998;46(2):146-51.

Institute of Laboratory Animal Resources (U.S.). Guide for the Care and Use of Laboratory Animals. Washington, D.C.: National Academy Press, 1996. p. 1-35.

Inui K, Schafer HJ, Aoki M, et al. Bronchial circulation after experimental lung transplantation: the effect of long-term administration of prednisolone. J Thorac Cardiovasc Surg. 1993;105:474-9

Jatene FB, Pêgo-Fernandes PM. Challenges in lung transplantation. J Bras Pneumol 2008;34(5):249-50.

Kai H, Yoshitake K, Hisatsune A, Kido T, Isohama Y, Takahama K, Miyata T. Dexametasone suppresses mucus production and Muc2 and Muc5acgene expression by $\mathrm{NCl}-\mathrm{H} 292$ cells. Am J Physiol Lung Cell Mol Physiol. 1996:271: L484-8.

Kalan BD, Van Bureu C, Flecher S, Payne WD, Baleau M, Kerman RH. Cyclosporine imunossupression mitigates immunologic risk factor in renal allotransplantation. Transp/ Proc. 1983; 15: 2469-78.

Kendall EC. The development of cortisone as a therapeutic agent. Nobel Lecture, December 11, 1950 [cited 2009 sept 15]. Avaible from: http://nobelprize.org/nobel_prizes/medicine/laureates/1950/kendalllecture.ht-ml.

Kirby TJ, Mehta A. Lung transplantation: state of the art. Appl Cardiopulm Pathophysiol.1992;4(4):263-71. 
Klosek JM, Laliberte F, Laliberte MF, et al. Local safety of intranasal triamcinolone acetonide: clinical and histological aspects of nasal mucosa in the long term treatment of perennial allergic rhinitis. Rhinology 2001; 39:17-22

Kondo C S, Machionne M, Nakagawa NK, Carvalho CRR, King M, Saldiva PHN, Lorenzi-Filho G. Effects of intravenous furesomide on mucociliary transport and reological properties of patients under mechanical ventilation. Critical Care. 2002:6; 81-87.

Kountz DS, Clark CL. Safely withdrawing patients from chronic glucocorticoid therapy. Am Fam Physician. 1997; 55:521-5.

Krishnam MS, Suh RD, Tomasian A, Goldin JG, Lai C, Brown K. Postoperative complications of lung transplantation: radiologic findings along a time *

Lima O, Golberg M, Peters WJ, Ayabe H, Townsend E, Cooper JD. Bronchial Omentopexy in canine lung transplantation. J Thorac Cardiovasc Surg 1982; 83:418-21

Lima O, Goldberg M, Peters WJ, Ayabe H, ToWsend E,Cooper JD. Bronchial omentopexy in canine lung transplantation. J Thorac Cardiovasc Surg, 1982;83:418-21

Longui CA. Glucocorticoid therapy: minimizing side effects. Jornal de Pediatria. 2007;82(5 suppl):S163-S171.

Lorenzi G, Bohm GM, Guimarães ET, Costa VMA, King M, Saldiva PHN. Correlation between rheologic properties and in vitro ciliary transport of rat nasal mucus. Biorheology 1992; v.29, p 433-440.

Lu W, Lillehoj EP, Kim KC. Effects of dexametasone on Muc5ac mucin production by primary airway globet cells. Am J Physiol Lung Cell Mol Physiol. 2005; 288:L52-60. 
Lund VJ. Nasal physiology: Neurochemical receptors, nasal cycle, and ciliary action. Allergy Asthma Proc 1996;17(4):179-8

Lundgren JD, Kaliner MA, Shelhamer JH. Mechanisms by which glucocorticosteroids inhibit secretion of mucus in asthmatic airways. Am Rev Respir Dis 1990; 141: S52-S58.

Machione M, Guimarães ET, Saldiva PH, Lorenzi Filho G. Methods for studying respiratory mucus and mucus clearance. Braz $J$ Med Biol Res 1995;28:1347-55.

Majima Y, Harada T, Shimizu T. Effect of Biochemical Components on Rheological Properties of Nasal Mucus in Chronic Sinusitis: American J Respir Crit Care Med 1999;160:421-6.

Marom Z, Shelhamer J Alling D, Kaliner M. The effects of corticosteroids om mucous glycoprotein secretion from human airways in vitro. Am Rev Respir Dis. 1984;129:62-65.

McAnally KJ, Valentine VG, Laplace SG, McFadden PM, Seoane L, Taylor DE. Effect of Pre-Transplantation Prednisone on Survival After Lung Transplantation. J heart and Lung Transplantation. 2006;25:67-74.

Medina LS, Siegel MJ, Glazer HS, Anderson DJ, Semenkovich J, Bejarano PA. Diagnosis of pulmonary complications associated with lung transplantation in children: value of CT vs histopathologic studies. AJR Am J Roentgenol. 1994;162(4):969-74.

Mills NL, Boyd AD, Gheranpong C. The significance of bronchial circulation in lung transplantation. J Thorac Cardiovasc Surg.1970;60:866-76

Miranda A, Zink R, McSweeney M. Anesthesia for lung transplantation. Semin Cardiothorac Vasc Anesth 2005;9(3):205-12. 
Murray JE, Tilney NL, Wilson RE. Renal transplantation: a twenty-five year experience. Ann Surg.1976;184;565-73.

Nelems B, Rebuk AS, Cooper JD. Human lung transplantation. Chest. 1980, 78: 569-73.

Neptune WB, Weller R, Bailey CP, Experimental lung transplantation. J Thorac Cardiovasc Surg 1953; 26: 606-15

Novick RJ, Menkis AH, Ahmad D. The safety of low dose prednisolone before and immediately after heart-lung transplantation. Ann Thorac Surg. $1991 ; 51: 642-45$

Orens BJ, Estenne M, Arcasoy S, Conte JV, Corris P, Egan JJ, Egan T, Keshavjee S, Knoop C, Kotlof R, Martinez FJ, Nathan S, Palmer S, Patterson A, Singer L, Snell G, Studer S, Vachiery JL, Glanville AR. International Guidelines for the Selection of Lung Transplant Candidates: 2006 Update-A Consensus Report From the Pulmonary Scientific Council of the International Society for Heart and Lung Transplantation. J Heart Lung Transplant 2006;25:745-55

Pazetti R, Pêgo-Fernandes PM, Lorenzi-Filho G, Saldiva PH, Moreira LF, Jatene FB. Effects of cyclosporine $A$ and bronchial transection on mucociliary transport in rats. Ann Thorac Surg 2008;85(6):1925-9.

Pazetti R, Pego-Fernandes PM, Ranzani OT, Parra ER, Lorenzi-Filho G, Jatene FB. Cyclosporin A reduces airway mucus secretion and mucociliary clearance in rats. Clinics 2007;62(3):345-52.

Pêgo-Fernandes P M, Samano MN, Junqueira JJM, Waisberg DR, Noleto GS, Jatene FB. Perfil do doador de pulmão disponibilizado no estado de São Paulo, Brasil, em 2006. J Pneumol 2008;7(34):497-505. 
Rennard SI, Romberg DI, Robbins RA, Spurzem JR. Is asthma a epithelial disease? Chest. 1995; 107:127-31.

Rivero DHRF, Lorenzi-Filho G, Pazetti R, Jatene FB, Saldiva PHN. Effects of bronchial section and reanastomosis on mucociliary system. Chest. 2001;119:1510-5.

Roitt IM. Imunologia. 5a. edição. Local: Atheneu; 1999.

Rubin BK, Ramirez O, King M. Mucus-depleted frog palate as a model for the study of mucociliary clearence. J Appl Physiol. 1990; 69 (2):424-29.

Saldiva, PHN. Aparelho mucociliar: Aspectos funcionais e métodos de estudo. Jornal de Pneumologia. Vol 16 161-170. 1990

Samano MNH, Minamoto H, Junqueira JJM, Yamaçake KGR, Gomes HAP, Mariani AW, Pêgo-Fernandes PM , Jatene FB. Bronchial Complications Following Lung Transplantation. Transplatation Proceedings 2009;41:921-926.

Sartir P, Sleigh, MA. The physiology of cilia and mucociliary interactions. Ann Rev Phisiol. 1990;52:137-155.

Schuhl, J F. Estudio del clearance muco-ciliar nasal en asmáticos extrinsecos atópicos. Reu Med Uruguay 1990; 6: 126-130

Shankar S, Fulsham L, Read RC, Theodoropoulos S, Cole PJ, Madden B, Yacoub M. Mucociliary function after lung transplantation. Transplant Proc. 1991;23:1222-3.

Stewart KC, Patterson GA. Current trends in lung transplantation. Am J Transplant. 2001;1(3):204-10. 
Studen SM, Levy RD, Mcneil K, Orens JB. Lung transplantation outcomes: a review of survival, graft function, physiology, health-related quality of life and cost-effectiveness. Eur Resp J. 2004;24:674-85.

Swingle W W, Pfiffner J J. The revival of comatose adrenalectomized cats with an extract of suprarenal cortex. Science.1930;72:75-76.

Tomkiewicz RP, Ernst M, Shennib H, Ramirez O, Nguyen D, King M. Airway mucus and epithelial function in a canine model of single lung autotransplantation. Chest. 1995;107:261-5.

Toronto Lung Transplant Group: Unilateral lung transplantation for pulmonary fibrosis. N Engl J Med 1986;314:1140.

Trindade SHK, Mello-Junior JF, Lorenzi-Filho G, Macchione M, Guimarães ET, Saldiva PHN. Methods for studying mucociliary transport. Rev Bras Otorrinolaringol. 2007; 73 (5):704-12..

Trulock E P., Jason D. Christie, Leah B. Edwards, Mark M. Boucek, Paul Aurora, David O. Taylor, Fabienne Dobbels, Axel O. Rahmel, Berkeley M. Keck, Marshall I. Hertz. Registry of the International Society for Heart and Lung Transplantation: Twenty-fourth Official Adult Lung and Heart-Lung Transplantation Report-2007. J of Heart and Lung Transplant. 2007;26(8):782-95.

Veale D, Glasper PN, Gascoigne A, Dark JH, Gibson GJ, Corris PA. Ciliary beat frequency in transplanted lungs. Thorax 1993;48:629-31.

Verdugo P, Johnson NT, Tam PY. ß-adrenergic stimulation of respiratory ciliary activity. American Physiological Society. 1980; 868-871.

Vondracek SF, Hemstreet BA. Is there an optimal corticosteroid regimen for the management of an acute exarcebation of chronic obstructive pulmonary disease? Pharmacotherapy.2006;26(4):522-32. 
Wagner JS, Headley AA. Cystic Fibrosis: Trends in Respiratory Care. Respir Care 48:234-245, 2003.

Wanner, A; Salathé, M; O’Riordan, TG. Mucociliary Clearence in the airways. Am J Respir Crit Care Med. 1996;154:1968-1902.

Xavier AM, Pêgo-Fernandes PM, Correia AT, Pazetti R, Monteiro R, Canzian $M$, Jatene FB. Influence of cyclosporine $A$ on mucociliary system after lung transplantation in rats. Acta Cir Bras 2007;22(6):465-9

Zanchet RC, Magalhães AC, Correia AF, Feijó G. A influência de bactérias patogênicas na transportabilidade do escarro e na qualidade de vida de portadores de bronquiectasia. Rev Bras Fisioter. 2006;10(3):457-463. 